\title{
The Use of Herbal Medicines by Cancer Patients in Contemporary African Settings: A Scoping Review
}

\author{
Bamidele J. Alegbeleye $^{1^{*}}$, Oke-Oghene P. Akpoveso ${ }^{2}$, and Rana K. Mohammed ${ }^{3}$ \\ 1Department of Surgery, St Elizabeth Catholic General Hospital \& Cardiac Center, Shisong P.0 Box 8, \\ Kumbo-Nso, Northwestern Region, Cameroon
} 2Department of Pharmacy, American International University West Africa, Kainifing Industrial
Layout, P.O Box 3505, The Gambia

\begin{abstract}
${ }^{3}$ Department of Biotechnology, College of Science, University of Baghdad, Baghdad, Iraq E-mail: drbalegbeleye@gmail.com; o.akpoveso@gmail.com; phd.rana.kadhim@gmail.com

*corresponding author details: Dr. Bamidele J. Alegbeleye, drbalegbeleye@gmail.com
\end{abstract}

\begin{abstract}
BACKGROUND: Patients in Africa frequently utilize medicinal herbs at large. Nonetheless, to date, there is a lack of data on concurrent use of herbs with conventional cancer therapies. This scoping review aimed to describe the use of medicinal herbs and their derived products by cancer patients in contemporary African settings.

METHODS: We identified relevant articles to date using a manual library search (PubMed), Embase Medline, Cochrane Library, Science Direct, Google Scholar, and Scientific Electronic Library Online (SciELO) for articles with information on medicinal plants with potential anti-cancer therapeutic properties in Central, Eastern, and Western Africa. We assessed 122 articles based on titles and abstracts, and 28 articles based on full text. Fourteen research articles fulfilled preset eligibility criteria.

RESULTS: The median prevalence of herbal and complementary medicine (H\&CM) use in our contemporary Africa settings was $60.0 \%$ (range: 13-80\%). Median percent disclosure of H\&CM use to attending healthcare professionals was low at 26\% (range: 10.3-78.8\%). H\&CM used by cancer patients included herbs, healing prayers, and massage. Reported reasons for the use of H\&CMs include i) the strong desire to get rid of cancer symptoms, especially pain, and the need to improve physical and psychological well-being. There were limited data on safety and risk profiles of H\&CM among cancer patients in our African settings.

CONCLUSION: Herbal and complementary medicines are frequently in use among cancer patients undergoing conventional cancer treatments. Healthcare professionals caring for cancer patients ought to inquire and communicate effectively regarding the use of H\&CM to minimize the risks of side effects from concurrent use of H\&CM and biomedicines. H\&CMs could give enormous opportunities for cancer and noncommunicable disease therapies, especially now that Africa's cancer burden is overwhelming. From the preceding, therefore, the benefit of H\&CM is fundamental in the preservation of threatens species and traditional knowledge. Consequently, a balanced approach and a mutually beneficial partnership between traditional medicine and Bio-medicine must be found by local and global health politics.
\end{abstract}

Keywords: herbal and complementary medicine; safety and risk profiles; cancer; conventional cancer therapy; Africa

\section{BACKGROUND}

Cancer has been one of the leading causes of human death for many years and has lately become a top killer among different human diseases $[1,2]$. Importantly, cancer brings about substantial treatment costs and lowers patients' quality and quantity of life. A recent report from the World Health Organization (WHO) indicated that approximately 14.1 million new cancer cases had been diagnosed in 2012 worldwide, with 8.2 million associated deaths $[1,3]$. The 2014 World Cancer Report, cancer incidences have rapidly increased in all regions of the world in the past decades. They are predicted to remain a significant cause of human death in the coming years. Therefore, cancer detection, prevention, and therapy will be the first topics of our research $[1,4]$.
Chemotherapy is routinely used for cancer treatment. Since cancer cells lose many of the regulatory functions present in healthy cells, they continue to divide when normal cells do not [5-9]. This feature makes cancer cells susceptible to chemotherapeutic drugs. Approximately five decades of systemic drug discovery and development have resulted in the establishment of an extensive collection of useful chemotherapeutic agents [5-9]. Interestingly, these conventional Chemotherapy therapies for the management of cancer have several side effects due to their lack of specificity and are limited in rural settings [10, 11]. Further, the current challenge is undaunted resistance of cancerous cells to cytotoxic drugs, giving unsatisfactory ministration outcomes and capricious resistance to antineoplastic agents [10-13]. Other limitations include the 
prohibitive costs, unavailability of allopathic drugs, and chronic poverty in Africa. As a matter of urgency, we must fold back on homegrown solutions, exploring flora and fauna in our contemporary settings [10, 14]. Besides, medicinal plants still have enormous potential to provide newer drugs and are a reservoir of natural chemicals that may give chemoprotective potential against cancer. Recently, Taneja and Qazi, have suggested several compounds from medicinal plants with potential anticancer activities and the likely mechanism of action of such plant products was equally discussed $[10,13]$.

In recent years, numerous African medicinal plants have been screened for their cytotoxic potential. This review covers plants and derived molecules from Central, Eastern, and Western Africa (CEWA) as a potential resource for cancer chemotherapy, emphasizing their molecular targets [15]. Group A: These are countries of Central Africa including Cameroon, Gabon, Equatorial Guinea, Central African Republic, Congo, Democratic Republic of Congo, São Tomé and Príncipe, Chad, Angola. Group B: These are countries of East Africa that comprises of Kenya, Uganda, Tanzania, Rwanda, Burundi, Sudan, Eritrea, Djibouti, Ethiopia, Somalia, Seychelles, Comoros, Mauritius Island, Madagascar, Mozambique, and Malawi. Group C: Covering Western African countries including Benin, Burkina Faso, Ivory Coast, Gambia, Ghana, Guinea, Guinea- Bissau, Cape Verde, Nigeria, Mali, Mauritania, Niger, Liberia, Senegal, Sierra Leone, and Togo. By embarking on this approach in our review analysis; therefore, we opined that the medicinal plants of CEWA described cover a considerable portion of the African continent [15].

\section{THE BURDEN OF CANCER IN AFRICA}

"Cancer moved from the third leading cause of death worldwide in 1990 to the second leading cause of death after cardiovascular disease since 2013, with more than 8 million deaths in 2013" [15-17]. "Although significant progress has been made in recent years in cancer prevention and treatment, the burden of cancer is increasing as a result of a growing and aging population worldwide, in addition to risk factors such as smoking, obesity, and diet" $[15,18,19]$. Interestingly, "to adequately allocate resources for prevention, screening, diagnosis, treatment, and palliative care, and to monitor its effectiveness, there is an urgent need for timely information on the burden of cancer for each country. It is worth noting that in several African countries, the cancer burden remains unclear in terms of reliable epidemiological data, though most practicing physicians recognize that the number of cases among patients visiting local health facilities increases progressively" $[15,20]$.

Moreover, "the global statistics showed that by 2030, an estimated 20 million new cancer cases are expected annually, $70 \%$ of which will be from developing countries. African countries will account for more than a million new cancer cases per year and have to cope with them despite a few cancer care services" $[15,21]$. "In Africa, about a third of cancer deaths are potentially preventable. In sub-Saharan Africa in 2002, more than half a million deaths from cancer were reported, with nearly $40 \%$ of chronic infections and smoking," $[15,21]$. "Due to the lack of necessary resources and infrastructure, most Africans, including those in CEWA, do not have access to cancer screening, early diagnosis, an appropriate treatment, or palliative care. For example, radiotherapy is available in only 21 of the 53 African countries, reaching less than $5 \%$ of the population. Consequently, patients are deprived of lifesaving treatment" $[15,21]$.

\section{OBJECTIVE OF THE STUDY}

This scoping review aimed to describe the use of medicinal herbs and their derived products by cancer patients in contemporary African settings.

\section{METHODS}

We identified relevant articles to date using a manual library search (PubMed), Embase Medline, Cochrane Library, Science Direct, Google Scholar, and Scientific Electronic Library Online (SciELO) for articles with information on medicinal plants with potential anticancer therapeutic properties in Central, Eastern and Western Africa (CEWA). The Google search was done covering the following periods between January 1 and July 30, 2020, for papers written in English and published in the last ten years. Interestingly, the search was conducted using different keywords, including names of countries within CEWA as above, which were combined during the literature search and where applicable. The Google search engine uses more general search terms and broadens the search utilizing the following key searched words: "Traditional medicine" OR "Complementary medicine" OR "Alternative medicine" OR "Medicine, traditional" [MeSH Terms] OR "Indigenous Medicine" OR "Medicine, Indigenous" [MeSH Terms] OR "African traditional medicine" OR "Complementary therapies" OR "Complimentary therapy" OR "Complementary Medicine" OR "Integrative Medicine." AND "Conventional treatment" OR "Conventional medicine" OR "Allopathic medicine" OR "Biomedicine" OR "Bio-medicine" OR "Modern medicine" OR "Western medicine." AND "Cancer" OR "Neoplasm" OR "Carcinoma" OR "Malignancy" OR “Tumors" OR “Tumor."

Interestingly, the last search was done on July 20, 2020. The search outputs were saved where possible on databases, and the authors received notification of any new searches meeting the search criteria from Science Direct, Scopus, and Google scholar. We assessed 122 articles based on titles and abstracts, and 28 articles based on full text. Fourteen articles fulfilled preset eligibility criteria.

\section{RESULTS AND DISCUSSION \\ HISTORICAL PERSPECTIVE}

The historical development and practice of herbal medicine (HM) is inherently a very longstanding one dated back to the Stone Age [22]. "The literature reported the Sumerians of Mesopotamia at about 5000BC, known for the utilization of herbal recipes on clay," [22]. Surprisingly, "the ancient Chinese, Indians, Egyptians, Babylonians, and Native Americans were all herbalists. The oldest known list of 385 herbal remedies is Shen Nung's Pen Ts'ao or Shennong Ben Cao Jing, dated 3000 BC; Besides, a Chinese herbal that is probably a compilation of an even older oral tradition," [22]. "By 1500BC, an Egyptian named Ebers Papirus documented about 850 herbal remedies, including Aloe vera, Ocimum basilicum, Acasia, onions, garlic, etc. Also, Hippocrates (400-377BC), who was known as the father of Western medicine and proposed the Hippocrates oath in use by physicians to date, promoted Greek and Roman herbs, equally removed superstition from disease and used the bark of willow tree extensively to manage pains during delivery" [22].

Furthermore, "the ancient Greeks and Romans were also renowned herbalists. Surgeons traveling with the Roman army spread their herbal expertise throughout the Roman Empire, in Spain, Germany, France, and England. Moreover, Dioscorides (40- 90BC) and Galen (131-200 $\mathrm{AD}$ ) were both Greek surgeons in the Roman army. They compiled herbals that remained the definitive materia medica texts for 1500 years," [22] 
"Through the middle ages, herbalism was preserved in the monasteries of Britain and mainland Europe. Before the establishment of universities in the eleventh and twelfth centuries, monasteries served as medical schools. Benedictine Monks (around 1000AD) copied and translated many of the works of Hippocrates, Dioscorides, and Galen. Their 'physick' gardens, wellstocked with the most common and useful medicinal herbs, served as primary training grounds for the next generation of physicians-monks and laymen alike" [22]. Meanwhile, "as a result of the Islamic conquest of North Africa in the seventh and eighth centuries, Arabic scholars acquired many Greek and Roman medical texts. Iranian physician Ibn Sina, also known as Avicenna (9801037 AD), combined the herbal traditions of Dioscorides and Galen with his people's ancient practices in The Canon of Medicine (al-Qanun fi at-tibb). One of the most influential medical texts ever had written Avicenna's Canon spread through Europe during the eleventh and twelfth centuries" [22]. "With the invention of the printing press in the mid-fifteenth century, the herbals of Dioscorides, Galen, and Avicenna were mass-produced and made accessible to people outside the palace, the monastery, and the university" [22].

In a related development, "the use of the herbals required no specialized skills; readers simply gathered the medicinal herbs and applied them in the prescribed manner and dosage, each physician-gardener who compiled a new herbal sought to revolutionize, or at least standardized, medicinal plants. One such writer was Theophrastus Bombastus von Hohenheim, better known as Paracelsus (1493-1541). He emphasized the importance of experience with patients and railed against blind faith in ancient physicians" [22]. "Despite his announced distrust of traditional herbalism, Paracelsus revived the first-century 'doctrine of signatures.' According to the doctrine of signatures, every herb has its own 'sign.' The appearance of the plant, and its color, scent, or living environment indicated its medicinal use. A century later, Englishman Nicholas Culpeper (16161654) revitalized another ancient facet of herbalism called astrology. Astrological herbalists connected herbs to different signs of the zodiac. They treated specific ailments by determining what sign and planet ruled over the body that needed care and then prescribing an herb of the same astrological sign" [22]. According to Culpeper, "he must know the reason for the operation of the Herbs, must look up as high as the stars. While Paracelsus and Culpeper promoted the doctrine of signatures and astrological herbalism, medical practice was changing. Men like Francis Bacon (1561-1626) and William Harvey (1578-1657) transformed science from a speculative to an experimental process," [22]. "This new emphasis did not mix well with the revival of the doctrine of signatures and astrology; thus, biological and medical science began to separate from traditional herbalism. The herbalists that focused on classification and refused to acknowledge 'signatures' and 'stars' ultimately formed botany science till date," [22]. "Physicians who found Harvey's circulation of the blood more useful than Culpeper's movements of the planets started what might be called scientific medicine. The four herbals highlighted in this exhibit are milestones in the history of western herbal medicine, from its classical source to its drift from medical science" [22].

AFRICAN TRADITIONAL MEDICINE IN PERSPECTIVE According to Ezekwesili-Ofili et al., "within the African context, the traditional healing practice of magic is much older than that of some conventional medical sciences and much more prevalent than orthodox medicine" [23, 24]. Several authors submitted that in African communities, "TM is characterized by a holistic health care system that is organized into three levels of specialty, which include divination, spiritualism, and herbalism. However, these may overlap in some situations," [23-27]. Meanwhile, "the WHO confirmed that HM had demonstrated the enormous potential of therapeutic benefits in its contribution to modern medicine. More than $30 \%$ of current drugs are derived directly or indirectly from medicinal plants. Examples of these medicines are analgesics (aspirin, belladonna), anti-cancer medicines (vincristine and vinblastine), antihypertensive agents (reserpine); antimalarials (quinine, artemisinin); and decongestants (ephedrine)" $[23,28,29]$.

"The official recognition of the TM and its practitioners made by the Alma Ata Declaration in 1978 amounted to a significant landmark and resources for achieving Health for All" [23, 28, 29]. "Since then, member states and WHO governing bodies have adopted several resolutions and declarations on TM. Notable among these is the decision on promoting the role of TM in health systems: A Strategy for the African Region adopted by the WHO Regional Committee for Africa in Ouagadougou, Burkina Faso, in 2000 and the declaration on the Decade of African Traditional Medicine (2001-2010) by the Heads of State and government in Lusaka in 2001" [23, 28, 29].

Globally, "clinicians frequently regard herbal medicine as an integral part of traditional medicine (TM)," [23, 30]. "The WHO defines TM as the knowledge, skills, and practices of any community based on existing theories, beliefs, and experiences indigenous to different cultures; Whether explicable or not, used in the maintenance of health and the prevention, diagnosis, improvement, or treatment of illness" $[23,30,31]$. From the above definition, the most critical differentiating niche to the TM systems is the capacity to meet the needs of the local communities over the years; therefore, the rise to the present sophisticated level by the Acupuncture and Ayurveda medicine in China and India is a typical example of TM development [23, 32]. "TM is now generally available, affordable, and commonly used in large parts of Africa, Asia, and Latin America. Therefore, it is estimated by the WHO that about $80 \%$ of the populations in developing countries still depend on TM for their Primary health care (PHC) needs" $[23,32]$. Interestingly, the percentage of individual's utilization of TM may vary from country to country $[23,33]$.

\section{HERBAL THERAPY FOR CANCER CARE}

Interestingly, "the battle against cancer in most contemporary African countries has not been easy for the following reasons. 1) A few numbers of specialists; 2) The lack of technical equipment; 3) The centralization of extensive health facilities in the country's capitals; 4) Insufficient supply of therapeutic surgery, chemotherapy and radiotherapy; and 5) The unaffordable costs of medicines and medical care make the patient's therapeutic program complicated" [34-37]. "Given these reasons mentioned above, it might not be surprising to see the traditional health practitioners (THPs) respond to most of the population's health needs. Therefore, the THPs take care of indigent patients by displaying affordable prices and providing available health products almost immediately," [34, 35].

"From existing reports in our settings, most cancer patients use herbal medicines alone as monotherapy or in combination with conventional medicine when available as polytherapy. Both therapeutic approaches are everyday use as soon as the disease is reported, and cancer treatments are administered. In the case of therapeutic failure, TM acts as palliative care and accompanies patients with terminal illness until the end. TM is first-line treatment as soon as a disease is developed, and it may be the only possibility of care in specific areas suffering from poor medical services," [34-37]. 
This type of behavior from cancer patients and the lack of an excellent medical system are typical in African populations. This situation explains the delay in going to the hospital or other health facilities [34-37]. "For cancer therapies, this represents both a delay in diagnosis and medical care. Not going to the hospital in due time has many consequences such as a) a high mortality rate, b) an increased level of pain and suffering because of the progression of the disease, c) a relatively higher cost for treatment, and d) a significant loss in their chance for recovery" [34-37].

\section{PLANTS AND CANCER TREATMENT OR PREVENTION}

"The two famous Persian Physicians (Rhazes and Avicenna), submitted that diseases need to be treated using a scheme consisting of three options; the first option is by using physiotherapy and diet, the second one is by using drugs, and the last option is surgery" [38, 39]. "Drugs used at that time have been classified as simple and compound drugs. Treatment of any disease will start with the simple one to avoid drug-drug interaction; unless it did not work, then the physician will use the compound drugs, and when the second option failed too, then surgery will be used" $[38,39]$. Regarding cancer treatment, 'Avicenna' mentioned that "if it is the start of cancer, it is possible to make it static and prevent it from growth and hence ulceration" [38, 40]. "Researchers mentioned that herbalbased medicines are one of the best choices for treating and preventing cancer incidence. This scenario is mainly because of the varieties of active substances that plants contain, which work against many cancers in several mechanisms," [38-44]. "These compounds can be extracted and can be used alone or in combination with other anticancer treatments. In comparison with synthetic drugs, these natural compounds are naturally available, cheaper, and easy to administer orally and have low or minimal side effects. They are found to be rich in various biologically active chemotypes," [38-44]. Avni and colleagues mentioned several plants work as "Chemopreventive agents against many types of cancers, like; Abrus precatorius on Yoshida sarcoma, Albizia lebbeck sarcoma, and Alstonia scholaries on forestomach carcinoma" [38, 45]. Other plants characterized by anti-cancer activity like "Anacardium occidentale in hepatoma, Asparagus racemosus in human epidermoid carcinoma, Boswellia serrata in human epidermal carcinoma of the nasopharynx, Erythrina suberosa in sarcoma, Euphorbia hirta in Freund virus leukemia, Gynandropsis pentaphylla in hepatoma, Nigella sativa in Lewis lung carcinoma, Paederia foetida in human epidermoid carcinoma of the nasopharynx, Mycorrhiza kurroa in hepatic cancers, and Withania somnifera in various tumors" [38, 45]. One of the most critical problems associated with cancer treatment is chemotherapy resistance. Researchers are trying their best to prevent or reduce the incidence of resistance by detecting new anti-cancer agents as an alternate $[38,40]$. Thazin and colleagues mentioned that "natural compounds extracted from plants could work as anti-cancer agents and restore chemotherapy sensitivity. For example, tetrandrine, which is an active alkaloid compound extracted from the plant, enhances doxorubicin anti-cancer activity against resistant MCF-1/DOX cells in vivo via modulating P-gp-mediated drug efflux. Another natural compound is quercetin (flavonoid), which restores daunorubicin chemosensitivity in resistant HL-60/DOX and K562/DOX cell lines via suppression of P-gp expression" [38, 46]. "Curcumin also increases vincristine chemotherapy activity in SGC7901/ VCR cell lines by suppressing $\mathrm{ABC}$ transporters such as P-gp, MRP1, and ABCG2 proteins" [38, 46]. "Jana and colleagues conducted in vitro study to determine the anti-cancer, antiproliferative, and cytotoxic effect of brassinosteroids (BRs) which are steroids extracted from plants against (MCF-
7/MDA-MB-468) breast and (LNCaP/ DU-145) prostate cancer cell lines and normal cell line. Results showed that RBs significantly arrested MCF-7, MDA-MB-468, and LNCaP cells in G1 phase of the cell cycle and induced apoptosis in MDA-MB-468, LNCaP, and slightly in the DU145 cells, without any toxic effect against normal cell lines. These results support the point that RB compounds are a promising source for anti-cancer drugs," [38, 47]. "Another in vitro study is conducted to detect the anti-proliferative and cytotoxic effect of the aqueous extract of $A$. ascalonicum against Wehi164 (mouse fibrosarcoma cells), Jurkat (human acute T-cell leukemia) and K562 (human erythroleukemia), and human umbilical vein endothelial cells (HUVEC) as a normal cell line" $[38,48]$. "Results showed that the extract showed a significant antiproliferative effect against all cancer cell lines and a dose and time cytotoxic effect against a normal cell line's shallow cytotoxic effect. These results showed that the Allium ascalonicum plant is a promising source for a potent anti-cancer treatment for several types of cancers," [38, 46]. About cancer prevention, it has been approved that several plants, herbs, and vegetables can prevent or reduce the incidence of cancer in several sites of the human body $[38,40]$. "An in vitro study is conducted by a group of researchers trying to detect ethyl acetate extract of onion (EEO) to cause cancer growth inhibition and apoptosis in human breast cancer MDA-MB-231. Results showed that EEO cause apoptosis for MDA-MB-231 breast cancer cell line and prevent incidence (i.e., growth) of breast cancer by inhibiting fatty acid synthase (FAS) production and accumulation in adipose tissues" [38, 49]. "Another in vitro study is conducted by Arif and colleagues to detect the antitumor effect of Aloe vera crude extract (ACE) alone and in combination with cisplatin on human breast carcinoma cell line (MCF-7) and human cervical carcinoma cell line (HeLa)" [38, 50]. The cytotoxic potential of Aloe vera crude extract alone or cisplatin in human breast (MCF-7) and cervical (HeLa) cancer cells were studied using cell viability assay, nuclear morphological examination, and cell cycle analysis. Effects were correlated with the modulation of expression of genes involved in cell cycle regulation, apoptosis, and drug metabolism by RT-PCR. "Results showed that exposure of cells to ACE resulted in considerable loss of cell viability in a dose- and timedependent fashion, which was found to be mediated by through the apoptotic pathway as evidenced by changes in the nuclear morphology and the distribution of cells in the different phases of the cell cycle"[38, 50]. Interestingly, "ACE did not have any significant cytotoxicity towards normal cells, thus placing it in the safe chemopreventive agent category. Further, the effects were correlated with the down-regulation of cyclin D1, CYP 1A1, and CYP 1A2 and increased expression of Bax and p21 in MCF-7 and HeLa cells. Also, a low-dose combination of ACE and cisplatin showed a combination index less than 1, indicating synergistic growth inhibition compared to the agents applied individually" $[38,50]$. Consequently, "these results signify that Aloe vera may be an effective antineoplastic agent to inhibit cancer cell growth and increase the therapeutic efficacy of conventional drugs like cisplatin; Thus promoting the development of plantderived therapeutic agents appears warranted for novel cancer treatment strategies" $[38,50]$.

\section{PLANT-DERIVED ANTI-CANCER DRUGS}

From evidence-based reports, "more than two-thirds of the anti-cancer treatments are extracted from plants. These drugs are divided into several classes depending on their pharmacological effect including anti-mitotics [vinca alkaloids (e.g., vincristine and vinblastine), podophyllotoxins (e.g., etoposide and teniposide), and taxanes (e.g., paclitaxel, docetaxel)], topoisomerase inhibitors [Topo I (e.g., topotecan and irinotecan), 
Topo II (e.g., ellipticine and podophyllotoxins)], ROS inducers (e.g., EGCG2 and thymoquinone), angiogenesis inhibitors (e.g., flavopiridol), histone deacetylases (HDAC) inhibitors (e.g., sulforaphane and pomiferin), and mitotic disruptors (e.g., roscovitine)" [39, 51, 52]. "An in vitro study is conducted by Maram and colleagues to detect the antitumor effect of Aloe vera $(A$. vera) and Calligonum extracts on hepatocellular carcinoma (HepG2) cells. Viability, apoptosis, and DNA damage of these cells have been tested after exposure to different concentrations of the two extracts. Results showed that the extracts of these two plants could have an antitumor effect against HepG2 cells; thus, these two plants can be promising sources for future anti-cancer treatment" [38, 53]. "Nadia and colleagues conducted an in vitro study in which the main aim was to detect the anti-cancer effect of ethyl acetate extract of Crataegus azarolus against HCT116 and HT-29 human colorectal cancer cell lines. Results showed that the extract demonstrated substantial cytotoxic and anti-growth activities via several mechanisms. Moreover, its apoptotic effect is associated with the elevation of p21 expression but not through p53 activation. As a result, the authors concluded that this compound could be used as an anti-cancer for treating colorectal cancer," [38, 54].

\section{PLANT- DERIVED SECONDARY METABOLITES FOR CANCER CARE}

Over time, "researchers detected that plants found to be enriched with natural compounds called secondary metabolites, these metabolites characterized by several points that make them active antitumor agents" [38, 41]. These compounds can be classified into "three main groups which are: terpenoids (polymeric isoprene derivatives and biosynthesized from acetate via the mevalonic acid pathway), phenolics (biosynthesized from shikimate pathways, containing one or more hydroxylated aromatic rings), and the extremely diverse alkaloids (non-protein nitrogen-containing compounds, biosynthesized from amino acids such as tyrosine, with a long history in medication)" [38, 41]. "Yearly several new metabolites are extracted from plants, but limited numbers have been used to synthesize new potent anticancer agents," [38, 41].

\section{RELIGIOUS AND MYSTICAL PRACTICES IN ANTI- CANCER THERAPIES}

"Besides medicinal plants, religious practices and mystics are among the therapeutic means of the African population to recover, remove the evil from which they suffer, and restore a broken physical harmony. Thus, many patients with cancer resort to rituals, usually in association with medicinal plants and conventional medicine when possible, such as exorcism, offering (sacrifices), fumigation, prayers, invocations, reading sacred texts of the Koran or the Bible, visits to places of worship, use of holy water (baths and drinks)" [34].

\section{ECONOMIC, ENVIRONMENTAL AND PUBLIC HEALTH ISSUES}

"The global market for traditional medicines has been steadily growing for several years and is valued at the US $\$ 60$ billion by the WHO. Strong links of interest exist between traditional medicine and conventional medicines. One-quarter (25\%) of current medicines come from the traditional pharmacopoeia" [34, 35 55-57]. "Ethnobotany and ethnopharmacology specialists work with traditional healers to select plants with strong curative potential; If useful and desired, bio-prospecting sometimes poses problems of patents and intellectual property almost always in disfavor of traditional healers" [34].
Consequently, "national and international laws must be enacted to regulate this type of prospecting to lead to mutually beneficial relationships and avoid biopiracy. In most African countries, this task of protecting cultural heritage, traditional knowledge, and medicinal plants remains to be done," [34, 57, 58]. Moreover, "overexploitation of certain plant species threatens them with extinction. It impoverishes biodiversity, which is made critical by forest fires or bush fires, excessive deforestation and unsustainable management of the environment. However, an unsuspected number of potentially anti-cancer molecules could originate from African ecosystems if a large-scale pharmaceutical prospecting activity is organized and regulated" $[34,56-$ 58].

Nonetheless, "the economic gains of HM cannot be overemphasized, which was also described as being highly lucrative in the international medical market. Annual revenues in Western Europe were estimated at the US $\$ 5$ billion in 2003-2004. In China, revenue is estimated at US\$ 14 billion in 2005. In Brazil, it was US\$ 160 million in 2007" $[23,59,60]$. "Despite these widely reported benefits globally, HM is not entirely harmless. The high levels of health risk of toxicity to their users have been reported for indiscriminate, irresponsible, or non-regulated use of several H\&CMs ; that may put the health of their users at risk of toxicity" [23, 61-65].

\section{STUDIES ON MEDICINAL HERBS USE IN AFRICA A. PREVALENCE OF MEDICINAL HERBS USE}

From the existing reports, as documented in Table 1 [66-78], we observed significant variations in the prevalence of the use of herbal medicines within and across countries. Notwithstanding the preceding fact, the median prevalence of H\&CMs use in our contemporary Africa settings was $60.0 \%$ (range: $13-$ $80 \%$ ) [66]. In an attempt to improve utilization of our abundant natural botanical resources; therefore, there is an urgent need to explore further the integration process between the biomedical health systems and traditional health practices in our contemporary African setting in a bid to promote patient safety and harmonious relationships. To date, only a few medical schools in Africa have incorporated aspects of H\&CM into their curricula [79].

\section{B. TYPES OF MEDICINAL HERBS USED BY CANCER PATIENTS}

In the other ten studies from Table 1, the H\&CMs used by cancer patients included herbs of various types, healing prayers or spiritual approaches, divination, massage, meditation, and animal products; for instance, python fat. Two of the studies included did not clearly state the medicinal herbs used by their study participants. Surprisingly, the reported prevalence of the use of each product varied significantly from study to study. In general, herbal products comprising various plant parts prepared in different forms constituted the most common herbal medicinal products in use [66].

\section{REASONS FOR USE OF MEDICINAL HERBS}

The study reported variations in the reasons for the use of H\&CMs including i) The strong desire to get rid of cancer symptoms, especially pain, ii) The passion for treating/cure cancer, iii) The need to improve physical and psychological well-being, iv) The will to treat toxicity of conventional cancer therapies and improve body immunity. Other include v) Fear of surgery, vi) Concern with the devil's influence in the disease process, and vi) The high cost of conventional cancer therapies were among the listed reasons for the use of H\&CMs. The preceding reports were obtained from eight of the 12 articles, where the 
authors exhaustively reviewed the various purposes by the cancer patients for utilizing H\&CMs, as seen in Table 1 [66-78]. Therefore, the use of H\&CM is likely to continue alongside conventional cancer treatments, mainly because it has long been part of the culture of the people and the patients trust H\&CM providers, and because of convenient methods of payment for H\&CM $[80,81]$. The studies reviewed herein showed that patients also use H\&CM because of dissatisfaction with conventional medical care, fear of surgery, and multiple side effects of traditional cancer medicines. H\&CMs are readily available and cheaper than traditional medicines [66, 82-86].

\section{OUTCOME OF MEDICINAL HERBS UTILIZATION}

Among cancer patients, we did not find any studies that objectively evaluated safety and risk profiles of H\&CMs use among cancer patients in our contemporary African settings. However, there were reports on perceived benefits and side effects of H\&CMs use. Perceived benefits from H\&CMs use included a) improved appetite, b) reductions in pain and other cancer symptoms, c) relaxation and improved sleep, d) improved emotional and physical well-being, e) improved ability to cope with illness, and e) preserved femininity and sex life [66].

From the existing reports, the observed side effects of concern include i) loss of weight, ii) general weakness and malaise, iii) nausea and vomiting, iv) diarrhea, v) itching, vi) skin rashes, vii) headaches, and viii) increased urinary frequency. Cancer patients who selfreported not using H\&CMs said they would not use them because of the reported side effects and perceived risks to internal organs, including the kidneys and liver. Besides, patients who used H\&CMs but did not experience any benefits comparable to their expectations would neither wish to use nor recommend it to other patients in the future [66].

\section{AFRICAN PLANTS AND COMPOUNDS WITH REGULAR SENSITIVITY AND COLLATERAL SENSITIVITY IN DRUG RESISTANT CANCER CELLS}

Research on the mode of action of botanicals and phytochemicals from the flora of Africa is not yet done systematically due to the lack of facilities and appropriate technology in research centers throughout the continent. However, the fight against multi-drug resistance (MDR) in cancer will provide conceptual clues on the actual sample-molecular targets [15]. In collaborations with more equipped research institutes in Western countries, plants and isolated compounds from the flora of CEWA were tested on cancer cells expressing well-known drug resistance phenotypes. The studies were mainly conducted by Professor Thomas Efferth (University of Mainz, Germany) and the team [15]. In Tables 2 [87195], results on samples are documented, which inhibited resistant cell lines with similar efficacy than sensitive ones (regular sensitivity). In some cases, it was observed that resistant cells were killed with even better efficacy than sensitive cells (hyper-sensitivity or collateral sensitivity). These plant extracts and phytochemicals could be especially useful to fight MDR in cancer. In this section, we will focus on plants and compounds exerting hypersensitivity on cell lines overexpressing ABC transporters, EGFR, and p53 knockout genes [15].

(A) Plants and Compounds Acting in Cancer Cells Over-Expressing ABC Transporters: Some botanicals and phytochemicals from CEWA were screened against ABC transporters-expressing cell lines. The most investigated cell lines included the P-gp-overexpressing CEM/ADR5000 leukemia cell line, the MRP1-expressing
HL60/AR leukemia cell line, and BCRP-expressing MDAMB231/BCRP breast adenocarcinoma cell line.

(B) Plants and compounds inducing hypersensitivity in these cell lines: These plants and compounds are summarized in Tables 2 [87-195]. The hypersensitivity of CEM/ADR5000 cells compared to its parental cell line CCRF-CEM was induced by Aframomum arundinaceum [87], Imperata cylindrica Beauv. var. koenigii Durand et Schinz (Poaceae) [114, 129-133], Nauclea pobeguinii (Pobég. ex Pellegr.) Merr. ex E.M.A. (Rubiaceae) [141-146], Pachypodanthium staudtii Engl \& Diels (Annonaceae) [101, 151-154], Piper capense L.f. (Piperaceae) [158-164] and Zingiber officinale Roscoe (Zingiberaceae)[186-195] etc.

(C) Plant extracts inducing hypersensitivity in MDAMB-231- BCRP clone 23 cells: When compared to its sensitive counterparts MDA-MB-231 cells; they include Aframomum polyanthum K. Schum (Zinziberaceae), Nauclea latifolia Smith. (Rubiaceae), Nauclea pobeguinii (Pobég. ex Pellegr.) Merr. ex E.M.A., Pachypodanthium staudtii Engl \& Diels and Uapaca togoensis Pax. (Euphorbiaceae) etc., [87-195].

(D) Plants and Compounds Acting in EGFR OverExpressing Cancer Cells: Several plant extracts and compounds were more active in the resistant glioblastoma U87MG.1EGFR cells than in its normal counterpart U87MG cells (DR < 0.90). They included: Albizia adianthifolia (Schum.) and Alchornea cordifolia (Schum. \& Thonn.) Müll.Arg., Anonidium mannii Engl. et Diels. (Annonaceae), Elaeophorbia drupifera (Thonn.) Stapf. (Euphorbiaceae), Erythrina sigmoidea Hua, Gladiolus quartinianus A. Rich (Iridaceae), Nauclea pobeguinii (Pobég. ex Pellegr.) Merr. ex EMA, Vepris soyauxii Engl. (Rutaceae) and Xylopia aethiopica (Dunal) A.Rich. (Annonaceae) etc., [87-195].

(E) Plants and Compounds Acting in p53 Knockout Cancer Cells: Botanicals inducing hypersensitivity in p53 knock-out cell line HCT116 (p53-/-) compared to its sensitive counterpart HCT116 (p53+/+) cell line included: Beilschmiedia acuta Kosterm (Lauraceae), Echinops giganteus var. lelyi (C. D. Adams) A. Rich. (Compositae), Erythrina sigmoidea Hua (Fabaceae), Nauclea latifolia Smith., Nauclea pobeguinii (Pobég. ex Pellegr.) Merr. ex EMA, Polyscias fulva (Hiern) Harms. (Araliaceae) and Uapaca togoensis Pax.. Compounds acting in p53 knock-out cancer cells included: alkaloid, benzophenone, etc., [87-195].

\section{KEY PANEL MESSAGE}

1. Current advances in healthcare research lead to the identification and characterization of most cancer types and corresponding cure.

2. The incidence and prevalence of most cancers are rising at a terrifying rate in both developed and developing countries because of various risk factors.

3. There is emerging improvement in synthetic drugs and hormonal therapy and the corresponding decline in cancer incidences, increased survival, and better life quality.

4. Prolonged synthetic anti-cancer drugs are linked with several health risks or side effects that result from the toxic influence of these drugs in healthy cells.

5. Chemoprevention by herbal compounds is of great interest and is considered to be an inexpensive, readily applicable, acceptable, and accessible approach to cancer control and management.

6. Herbal remedies play a significant role in the management of cancer and the associated therapeutic toxicity. 
7. The adjunct use of herbal products and chemotherapy can be an efficient and cost-effective way to treat most cancers.

8. Such adjuvant therapy proved to produce a synergistic anti-cancer effect that reduced drug toxicity, suppresses drug resistance, and provides quick drug action enhancing the quality of treatment.

9. Besides, combination therapy might also increase the synthetic partner's therapeutic index by improving the efficiency of the drug.

10. Plant-derived anti-cancer drugs such as vinblastine, vincristine, taxols, etc. showed encouraging chemotherapeutic potential that is currently used in cancer treatment, especially breast cancers and a large number of them are in preclinical or in clinical trials.

11. In the last decade, a vast number of phytochemicals were identified that showed encouraging anti-cancer Medicinal Plants - Use in Prevention and Treatment of Diseases.

12. Interestingly, several compounds like artemisinin and isothiocyanates showed selective toxicity toward cancer cells, which recommend these compounds' clinical trials.

13. Furthermore, phytoestrogens with affinity and capacity to produce functional responses through estrogen receptors revealed unique possibilities of using them in hormone replacement therapy.

14. Overall, this review can conclude that understanding the molecular mechanism of interaction between herbal compounds and cancer cells in the tumoral environment can help us to design novel anti-cancer drugs that are less toxic and affordable.

15. This review reflects that these goals will only be attainable if the herbal compounds that showed promising anti-cancer activity can be successfully transferred to an ideal clinical setting for the use of herbal therapies.

\section{CONCLUSION}

The current evidence supports that most cancer patients undergoing conventional cancer therapies in our contemporary African settings use H\&CMs concurrently with conventional cancer therapies. Unfortunately the majority of cancer patients do not disclose the use of $\mathrm{H} \& \mathrm{CM}$ to the healthcare professionals providing them with traditional cancer therapies. Nondisclosure of H\&CM concurrently with traditional cancer treatments to the healthcare professionals potentially exposes patients to danger, including side effects of H\&CM and interactions between the drugs and herbs. Cancer patients need to be encouraged to disclose the use of H\&CM to their healthcare professionals, who need to be more courteous when they deal with matters of H\&CMs.

The present scoping review made significant efforts at summarizing relevant data on the potential of medicinal plant and isolated natural products from Central, Eastern, and Western Africa to combat cancer with emphasis on their possible cellular targets. However, few research teams in the continent are already involved in the cytotoxic drug discovery from botanical sources, and it is expected that this study will stimulate other researchers, in the long run, to undertake similar research projects to valorize the African flora better.

\section{DECLARATIONS}

ACKNOWLEDGMENTS: Not Applicable

FUNDING: No record of funding for this study declared AVAILABILITY OF DATA AND MATERIALS: All data generated or analyzed during this study are included in this published article

DISCLOSURES: Not Applicable
AUTHORS' CONTRIBUTIONS: The Authors conceived of the study and participated in its design and coordination as well as helped to draft the manuscript; the author also read and approved the final manuscript.

ETHICAL APPROVAL: Not Applicable

COMPETING INTERESTS: The Authors declare that

there are no competing interests

\section{REFERENCES}

[1] Zhong C, Wall NR, Zu Y, Sui G. Therapeutic Application of Natural Medicine Monomers in Cancer Treatment. Current Medicinal Chemistry, 2017; 24: 1-16. DOI:10.2174/0929867324666170714101503

[2] Siegel RL, Miller KD, Jemal A. Cancer statistics, 2015. CA Cancer J Clin, 2015; 65 (1): 5-29.

[3] Ferlay J, Soerjomataram I, Dikshit R, Eser S, Mathers C, Rebelo $\mathrm{M}$ et al. Cancer incidence and mortality worldwide: sources, methods and major patterns in GLOBOCAN 2012. Int J Cancer, 2015; 136 (5): E359-386.

[4] McGuire S. World Cancer Report 2014. Geneva, Switzerland: World Health Organization, International Agency for Research on Cancer, WHO Press, 2015. Adv Nutr, 2016; 7 (2): 418-419.

[5] Desai AG, Qazi GN, Ganju RK, El-Tame M, Singh J, Saxena AK. Medicinal Plants and Cancer Chemoprevention. Curr Drug Metab. 2008 September; 9(7): 581-591.

[6] Sener SF, Grey NJ. The global burden of cancer. Surg. Oncol. 2005; 92(1):1-3. DOI: 10.1002/jso.20335 [PubMed: 16180214]

[7] Parkin DM. International variation. Oncogene. 2004; 23(38):6329-6340. doi:10.1038/sj.onc.1207726

[8] Parkin DM, Bray F, Ferlay J, Pisani P. Estimating the world cancer burden: Globocan 2000. Int J Cancer. 2001; 94(2):153-156. doi:10.1002/ijc.1440

[9] Jemal A, Siegel R, Ward E, Murray T, Xu J, Thun MJ. Cancer statistics, 2007. CA Cancer J Clin. 2007; 57(1):43-66. doi:10.3322/canjclin.57.1.43

[10] Omara T, Kiprop AK, Ramkat RC, Cherutoi J, Kagoya S, Nyangena DM et al. Medicinal Plants Used in Traditional Management of Cancer in Uganda: A Review of Ethnobotanical Surveys, Phytochemistry, and Anticancer Studies. Hindawi -Evidence-Based Complementary and Alternative Medicine Volume 2020, Article ID 3529081, 26 pages. https://doi.org/10.1155/2020/3529081

[11] Nguyen C, Mehaidli A, Baskaran K et al., "Dandelion root and lemongrass extracts induce apoptosis, enhance chemotherapeutic efficacy, and reduce tumor xenograft growth in vivo in prostate cancer," Evidence-Based Complementary and Alternative Medicine, vol. 2019, Article ID 2951428, 12 pages, 2019.

[12] Singh A, Settleman J. "EMT, cancer stem cells and drug resistance: an emerging axis of evil in the war on cancer." Oncogene 2010; 29 (34): 4741-4751

[13] Luqmani YA. "Mechanisms of drug resistance in cancer chemotherapy," Medical Principles and Practices 2005; 14 (1): 35-48

[14] New Vision, Uganda Should Invest in Herbal Medicine Research to Fight Cancer, 2018. https://www.newvision.co.ug/ new_vision/news/1484720/uganda-invest-herbalmedicineresearch-fight-cancer

[15] Mbaveng AT, Kuete V and Efferth T Potential of Central, Eastern and Western Africa Medicinal Plants for Cancer Therapy: Spotlight on Resistant Cells and Molecular Targets. Front. Pharmacol. 2017; 8:343. doi: 10.3389/fphar.2017.0034 
[16] Murray CJ, Lopez AD. Mortality by cause for eight regions of the world: global burden of disease study. Lancet 1997; 349: 1269-1276. doi: 10.1016/S01406736(96)07493-4

[17] Lozano R, Naghavi , Foreman K, Lim S, Shibuya K, Aboyans $\mathrm{V}$ et al. Global and regional mortality from 235 causes of death for 20 age groups in 1990 and 2010: a systematic analysis for the Global Burden of Disease Study 2010. Lancet 2012; 380: 20952128. doi: 10.1016/S0140-6736(12)61728-0

[18] Edwards BK, Noone AM, Mariotto AB, Simard EP, Boscoe FP, Henley SJ et al. Annual Report to the Nation on the status of cancer2014; 1975-2010, is featuring prevalence of comorbidity and impact on survival among persons with lung, colorectal, breast, or prostate cancer. Cancer 2014; 120: 1290-1314. doi: 10.1002/cncr.28509

[19] Allemani C, Weir HK, Carreira H, Harewood R, Spika D, Wang XS et al. Global surveillance of cancer survival 1995-2009: Analysis of individual data for 25,676,887 patients from 279 population based registries in 67 countries (CONCORD-2). Lancet 2015; 385: 977-1010. doi: 10.1016/S01406736(14)62038-9

[20] Omosa LK, Midiwo JO, Masila VM, Gisacho BM, Munayi R, Francisca K et al. Cytotoxicity of 91 Kenyan indigenous medicinal plants towards human CCRFCEM leukemia cells. J. Ethnopharmacol. 2015; 179: 177-196. doi: 10.1016/j.jep.2015.12.028

[21] Vorobiof DA, and Abratt R. The cancer burden in Africa. S. Afr. Med. J 2007; 97: 937-939.

[22] A Brief History of Herbalism. Historical Collections at the Claude Moore Health Sciences Library. Published by the University of Virginia. USA. (Assessed on July $24,2020)$. http://exhibits.hsl.virginia.edu/herbs/brief-history/

[23] Alegbeleye BJ. Traditional Medical Practice: An Appraisal of the Experience in Cameroon. International Journal of Healthcare Sciences ISSN 2348-5728 (Online) Month: October 2019 - March 2020; Vol. 7, Issue 2, pp: (49-62). Available at: www.researchpublish.com

[24] Ezekwesili-Ofili JO, Okaka ANC. Herbal Medicines in African Traditional Medicine. Intechopen Book 2019; chp 10: pg 191-214.

[25] Natako L. Honoring the African Traditional Herbalist; African Traditional Herbal Research Clinic Newsletter. Special Edition-HIV/AIDS. 25 years. 2006; 1(10).

[26] Chavunduka EL. Christianity, African Religion and African Medicine in World Council of Churches. 1990. Available from: http://wcc.coe.org/wcc/what/interreligions/cd33 -02. htm [Accessed: July 15, 2020]

[27] Mahomoodally MF. Traditional Medicine in Africa: An Appraisal of Ten Potent African Medicinal Plants Evidence Based Complementary and Alternative Medicine. Epub December 3, 2013. DOI: 10.1155/2013/617459 [Accessed: July 20, 2020]

[28] World Health Organization. Primary health care. Geneva: World Health Organization. 1978.

[29] World Health Organization. "Traditional medicine" WHO Fact Sheet 1996; 134: 3 pp.

[30] Oreagba IA, Oshikoya KA, Amachree M. Herbal medicine use among urban residents in Lagos, Nigeria. BMC Complementary and Alternative Medicine 2011; 11:117:1-8

[31] WHO Media Centre: Traditional Medicine. Fact sheet $\mathrm{N}^{\circ} 1342008$ [http:// www.who.int/mediacentre/ factsheets/ fs134/en/], (Accessed July 2020).

[32] World Health Organization: Traditional Medicine Strategy 2002-2005. WHO/EDM/TRM/2002.1,
Geneva 7 [http://whqlibdoc.who.int/hq/2002/ who_edm_trm_2002.1.pdf], (Accessed July 2020).

[33] World Health Organization: National policy on traditional medicine and regulation of herbal medicines- report of a WHO global survey. WHO 2005[http://apps.who.int/medicinedocs/pdf/s791 6e/s7916e.pdf], (Accessed July 2020).

[34] Ly A. Traditional Medicines and Cancer Therapies in African Landscape. J Tumor Med Prev. 2018; 3(1): 555601. DOI:10.19080/JTMP.2018.03.555601

[35] Ly A, Khayat D. About cancer in Africa: from epidemiology to biomedical applications and perspectives. National Cancer Institute, Boulogne Billancourt, Paris, France. 2006.

[36] Livingston J. Improvising medicine, an African oncology ward in an emergency cancer epidemic. Duke University Press, 2012; p. 248.

[37] Ly A. Global health, cancer challenges and control in African settings. Cancer Therapy \& Oncol Int J 2016; 2(3): 1-4.

[38] Bassam Hassan. In: Intechopen- Plants and Cancer Treatment; (Medicinal Plants use in Prevention and Treatment of Diseases). DOI:http://dx.doi.org/10.5772/intechopen.90568

[39] Zaid H, Silbermann M, Ben-Arye E, Saad B. Greco-Arab and Islamic herbal derived anticancer modalities: From tradition to molecular mechanisms. Evidencebased Complementary and Alternative Medicine 2012;2012:1-14

[40] Ahmad R, Ahmad N, Naqvi AA, Shehzad A, Al-Ghamdi MS. Role of traditional Islamic and Arabic plants in cancer therapy. Journal of Traditional and Complementary Medicine. 2016;7(2):195-204

[41] [16] Seca AM, Pinto DC. Plant secondary metabolites as anticancer agents: Successes in clinical trials and therapeutic application. International Journal of Molecular Sciences 2018;19(263):1-22

[42] Wu CP, Ohnuma S, Ambudkar SV. Discovering natural product modulators to overcome multidrug resistance in cancer chemotherapy. Current Pharmaceutical Biotechnology 2011;12(4):609-620

[43] Sak K. Chemotherapy and dietary phytochemical agents. Chemotherapy Research and Practice 2012;2012:1-11

[44] Lichota A, Gwozdzinski K. Anticancer activity of natural compounds from plant and marine environment. International Journal of Molecular Sciences 2018;19:1-38

[45] Desai AG, Qazi GN, Ganju RK, El-Tamer M, Singh J, Saxena AK etal. Medicinal plants and cancer chemoprevention. Current Drug Metabolism. 2008;9(7):581-591

[46] Aung TN, Zhipeng Q, Daniel Kortschak R, Adelson DL. Understanding the effectiveness of natural compound mixtures in cancer through their molecular mode of action. International Journal of Molecular Sciences 2017;18(656):1-20

[47] Malıkova J, Swaczynova J, Kolar Z, Strnad M. Anticancer and anti-proliferative activity of natural brassinosteroids. Phytochemistry 2008;69:418-426

[48] Mohammadi-Motlagh HR, Mostafaie A, Mansouri K. Anticancer and anti-inflammatory activities of shallot (Allium ascalonicum) extract. Archives of Medical Science 2011; 7(1):38-44

[49] Wang Y, Tian WX, Ma XF. Inhibitory effects of onion (Allium cepa L.) extract on proliferation of cancer cells and adipocytes via inhibiting fatty acid synthase. Asian Pac J Cancer Prev. 2012; 13(11):5573-5579. doi:10.7314/apjcp.2012.13.11.55735579

[50] Hussain A, Sharma C, Khan S, Shah K, Haque S. Aloe vera inhibits proliferation of human breast and cervical cancer cells and acts synergistically with 
cisplatin. Asian Pacific Journal of Cancer Prevention. 2015;16(7):2939-2946

[51] Dolan S. Anaemia. In: Brighton D, Wood M, editors. The Royal Marsden Hospital Handbook of Cancer Chemotherapy. London, England: Churchill Livingstone, Elsevier; 2005

[52] Henry L. Malnutrition. In: Brighton D, Wood M, editors. The Royal Marsden Hospital Handbook of Cancer Chemotherapy. London, England: Churchill Livingstone, Elsevier; 2005

[53] Shalabi M, Khilo K, Zakaria MM, Elsebaei MG, Abdo W, Awadin W. Anticancer activity of Aloe vera and Calligonum comosum extracts separately on hepatocellular carcinoma cells. Asian Pacific Journal of Tropical Biomedicine. 2015;5(5):375-381

[54] Mustapha N, Pinon A, Limami Y, Simon A, Ghedira K, Hennebelle T, et al. Crataegus azarolus leaves induce antiproliferative activity, cell cycle arrest, and apoptosis in human HT-29 and HCT-116 colorectal cancer cells. Journal of Cellular Biochemistry. 2016;117(5):1262-1272

[55] WHO. Traditional medicine strategy for 2002-2005. World Health Organization, Geneva, Switzerland. 2002: p. 70.

[56] WHO. Traditional medicine strategy for 2014-2023. World Health Organization, Geneva, Switzerland. 2014: p. 76

[57] 11. Chibale K, Davies-Coleman M, Masimirembwa C. Drug discovery in Africa: effects of genomics, natural products, traditional medicines, insights into medicinal chemistry, and technology platforms in pursuit of new drugs. Springer-Verlag; Berlin Heidelberg, Germany.2012.

[58] Ly A. Cancer and alternative therapies in Africa. Herbals and natural remedies, Herbals Summit 2015, October 26-27; 2015. Chicago, USA,

[59] World Health Organization. Primary health care. Geneva: World Health Organization. 1978.

[60] World Health Organization. Traditional medicine, WHO Fact Sheet 1996; 134: 3 pp.

[61] Kloucek P, Polesny Z, Svobodova B, Vlkova E, Kokoska L. Antibacterial screening of some Peruvian medicinal plants used in Callería District. Journal of Ethnopharmacology 2005; 99:309-312.

[62] Nnorom IC, Osibanjo O, Eleke C. Evaluation of human exposure to Lead and Cadmium from some local Nigerian Medicinal preparations. Journal of Applied Science 2006; 6: 2907-2911.

[63] Bury RW, Fullinfaw R0. Problem with herbal medicines. Medical Journal of Australia 1987; 146:324-325.

[64] Abt AB, Oh JY, Huntington RA, Burkhart KK. Chinese herbal medicine induced acute renal failure. Archives of Internal Medicine 1995; 155:211-212

[65] Alegbeleye BJ. Traditional bonesetting practices in the Northwest Region of Cameroon. East Cent Afr J Surg. 2019; 24(1):47-60

[66] Mwaka AD, Abbo C, Kinengyere AA. Traditional and Complementary Medicine Use among Adult Cancer Patients Undergoing Conventional Treatment in Sub-Saharan Africa: A Scoping Review on the Use, Safety and Risks. Cancer Management and Research 2020; 12: 3699-3712. http://doi.org/10.2147/CMAR.S251975

[67] Asuzu CC, Elumelu-Kupoluyi T, Asuzu MC, Campbell OB, AkinOdanye EO, Lounsbury D. A pilot study of cancer patients' use of traditional healers in the Radiotherapy Department, University College Hospital, Ibadan, Nigeria. Psycho Oncol. 2017; 26(3):369- 376. doi:10.1002/pon.4033

[68] Aliyu UM, Awosan KJ, Oche MO, Taiwo AO, Jimoh AO, Okuofo EC. Prevalence and correlates of complementary and alternative medicine use among cancer patients in Usmanu Danfodiyo university teaching hospital, Sokoto, Nigeria. Niger J Clin Pract. 2017; 20

doi:10.4103/njcp.njcp_88_17

(12):1576-1583.

[69] Aziato L, Clegg-Lamptey JNA. Breast cancer diagnosis and factors influencing treatment decisions in Ghana. Health Care Women Int. 2015; 36(5):543-557. doi:10.1080/07399332.2014.911299

[70] Ezeome ER, Anarado AN. Use of complementary and alternative medicine by cancer patients at the University of Nigeria Teaching Hospital, Enugu, Nigeria. BMC Complement Altern Med. 2007; 7:28. doi:10.1186/1472-6882-7-28

[71] De Boer C, Niyonzima N, Orem J, Bartlett J, Zafar SY. Prognosis and delay of diagnosis among Kaposi's sarcoma patients in Uganda: a cross-sectional study. Infect Agent Cancer. 2014; 9(17):1750-9378. doi:10.1186/1750-9378-9-17

[72] Erku DA. Complementary and alternative medicine use and its association with quality of life among cancer patients receiving chemotherapy in Ethiopia: a cross-sectional study. Evid Based Complement Alternat Med. 2016; doi:10.1155/2016/2809875

[73] Kiraki MW, Mbugua G, Mburugu RK. Use of complementary and alternative medicine among cancer patients in Meru County, Kenya. Int J Prof Pract. 2019; 7(1):24-33.

[74] Kiwanuka F. Complementary and alternative medicine use: influence of patients' satisfaction with medical treatment among breast cancer patients at Uganda Cancer Institute. Adv Biosci Clin Med. 2018; 6 (1):24-29. doi:10.7575/aiac.abcmed.v.6n.1p.24

[75] Mwaka AD, Mangi SP, Okuku FM. Use of traditional and complementary medicines by cancer patients at a national cancer referral facility in a low-income country. Eur J Cancer Care (Engl). 2019; 28 (6):e13158. doi:10.1111/ecc.13158

[76] Nwankwo TO, AJah L, Ezeome IV, Umeh UA, Aniebue UU. Complementary and alternative medicine. Use and challenges among gynaecological cancer patients in Nigeria: experiences in a tertiary health institution - preliminary results. Eur J Gynaecol Oncol. 2019; 40(1):101-105.

[77] Ong'udi M, Mutai P, Weru I. Study of the use of complementary and alternative medicine by cancer patients at Kenyatta National Hospital, Nairobi, Kenya. J Oncol Pharm Pract. 2019; 25(4):918- 928. doi:10.1177/1078155218805543

[78] Yarney J, Donkor A, Opoku SY et al. Characteristics of users and implications for the use of complementary and alternative medicine in Ghanaian cancer patients undergoing radiotherapy and chemotherapy: a cross- sectional study. BMC Complement Altern Med. 2013; 13 (1):16. doi:10.1186/1472-6882-13-16

[79] Chitindingu E, George G, Gow J. A review of the integration of traditional, complementary and alternative medicine into the curriculum of South African medical schools. BMC Med Educ. 2014; 14 (1):40. doi:10.1186/1472-6920-14-40

[80] Rutebemberwa E, Lubega M, Katureebe SK, Oundo A, Kiweewa F, Mukanga D. Use of traditional medicine for the treatment of diabetes in Eastern Uganda: a qualitative exploration of reasons for choice. BMC Int Health Hum Rights 2013; 13:1. doi:10.1186/1472-698X-13- 1

[81] Falisse JB, Masino S, Ngenzebuhoro R. Indigenous medicine and biomedical health care in fragile settings: insights from Burundi. Health Policy Plan 2018; 33(4):483-493. doi:10.1093/heapol/czy00 
[82] Osemene KP, Elujoba AA, Ilori MO. A comparative assessment of herbal and orthodox medicines in Nigeria. Niger J Nat Prod Med 2013; 17:77-81.

[83] Duru CB, Diwe KC, Uwakwe KA. Combined orthodox and traditional medicine use among hous eholds in Orlu, Imo State, Nigeria: prevalence and determinants. World Journal of Preventive Medicine 2016; 4:5-11

[84] Bamidele JO, Adebimpe WO, Oladele EA. Knowledge, attitude and use of alternative medical therapy amongst urban residents of Osun State, southwestern Nigeria. Afr J Tradit Complement Altern Med 2009; 6:281-288

[85] James PB, Wardle J, Steel A, Adams J. Traditional, complementary and alternative medicine use in SubSaharan Africa: a systematic review. BMJ Global Health. 2018;3(5):e000895. doi:10.1136/ bmigh2018-000895.

[86] Gondos A, Brenner H, Wabinga H, Parkin DM. Cancer survival in Kampala, Uganda. Br J Cancer. 2005; 92(9):1808-1812. doi:10.1038/ sj.bjc.6602540

[87] Kuete V, Ango PY, Yeboah SO, Mbaveng AT, Mapitse $\mathrm{R}$, Kapche GD et al. Cytotoxicity of four Aframomum species (A. arundinaceum, A. alboviolaceum, A. kayserianum and A. polyanthum) towards multifactorial drug resistant cancer cell lines. BMC Complement. Altern. Med. 2014a; 14:340. doi: 10.1186/1472-6882-14-340

[88] Kuete V, Efferth T. African flora has the potential to fight multidrug resistance of cancer. BioMed. Res. Int. 2015:914813. doi: 10.1155/2015/914813

[89] Ayafor JF, Tchuendem MHK, Nyasse B, Tillequin F, Anke H. Aframodial and other bioactive diterpenoids from Aframomum species. Pure Appl. Chem. 1994; 66: 2327-2330. doi: 10.1351/pac199466102327

[90] Watt J, Breyer-Brandwyk M. The Medicinal and Poisonous Plants of Southern and Easthern Africa. London: Livingstone. 1962.

[91] Van Wyk B, Gericke N. Peoples Plants: A Guide to Useful Plants in Southern Africa. Pretoria: Brizza Publications. 2000.

[92] Haddad M, Laurens V, Lacaille-Dubois MA. Induction of apoptosis in a leukemia cell line by triterpene saponins from Albizia adianthifolia. Bioorg. Med. Chem. 2004; 12: 4725-4734. doi: 10.1016/j.bmc.2004. 06.025

[93] Haddad M, Miyamoto T, Laurens V, Lacaille-Dubois MA. Two new biologically active triterpenoidal saponins acylated with salicylic acid from Albizia adianthifolia. J. Nat. Prod. 2003; 66: 372-377. doi: 10.1021/np020391q

[94] Kuete V, Tchinda CF, Mambe FT, Beng VP, Efferth T. Cytotoxicity of methanol extracts of 10 Cameroonian medicinal plants towards multi-factorial drugresistant cancer cell lines. BMC Complement. Altern. Med. 2016e; 16:267. doi: 10.1186/s12906-0161253-3

[95] Tamokou JDD, Simo Mpetga DJ, Keilah Lunga P, Tene M, Tane P, Roger Kuiate J. Antioxidant and antimicrobial activities of ethyl acetate extract, fractions and compounds from stem bark of Albizia adianthifolia (Mimosoideae). BMC Complement. Altern. Med. 2012; 12: 99. doi: 10.1186/1472-688212-99

[96] Ogungbamila FO, Samuelsson G. Smooth muscle relaxing flavonoids from Alchornea cordifolia. Acta Pharm. Nord. 1990; 2: 421-422.

[97] Adeneye AA, Oreagba AI, Ishola IO, Kalejaiye HA. Evaluation of the anti-arthritic activity of the hydroethanolic leaf extract of Alchornea cordifolia in rats. Afr. J. Tradit. Complement. Altern. Med. 2014; 11: 402-410. doi: 10.4314/ajtcam.v11i2.26
[98] Zorofchian Moghadamtousi S, Rouhollahi E, Karimian H, Fadaeinasab M, Firoozinia M, Ameen Abdulla M et al. The chemopotential effect of Annona muricata leaves against azoxymethane-induced colonic aberrant crypt foci in rats and the apoptotic effect of acetogenin Annomuricin E in HT-29 cells: a bioassay-guided approach. PLOS ONE 2015; 10:e0122288. doi: 10.1371/journal.pone.0122288

[99] Rajeswari D, Vijayalakshmi S, Gajalakshmi S. Phytochemical and pharmacological properties of Annona muricata. Int. J. Pharm. Pharmaceut. Sci. 2012; 4: 3-6.

[100] Kuete V, Sandjo LP, Wiench B, Efferth T. Cytotoxicity and modes of action of four Cameroonian dietary spices ethno-medically used to treat Cancers: Echinops giganteus, Xylopia aethiopica, Imperata cylindrica and Piper capense. J. Ethnopharmacol 2013c; 149: 245-253. doi: 10.1016/j.jep.2013.06.029

[101] Kuete V, Dzotam JK, Voukeng IK, Fankam AG, Efferth T. Cytotoxicity of methanol extracts of Annona muricata, Passiflora edulis and nine other Cameroonian medicinal plants towards multifactorial drug resistant cancer cell lines. Springerplus 2016b; 5: 1666. doi: 10.1186/s40064016-3361-4

[102] Torres MP, Rachagani S, Purohit V, Pandey P, Joshi $\mathrm{S}$, Moore ED et al. Graviola: a novel promising natural-derived drug that inhibits tumorigenicity and metastasis of pancreatic cancer cells in vitro and in vivo through altering cell metabolism. Cancer Lett. 2012; 323: 29-40. doi: 10.1016/j.canlet.2012.03.031

[103] Thomas J, Bahuchets S, Epelboin A, Furniss S. Encyclopédie des Pygmées Aka: Techniques, Langage et Société des Chasseurs-Cueilleurs de la Forêt Centrafricaine (Sud-Centrafrique et NordCongo). Paris: Peeters, (eds.). (2003). 1981-2010.

[104] Noumi E, Eloumou M. Syphilis ailment: prevalence and herbal remedies in Ebolowa subdivision (South region, Cameroon). Int. J. Biomed. Pharmaceut. Sci. 2011; 2: 20-28.

[105] Betti J. An ethnobotanical study of medicinal plants among the Baka Pygmies in the Dja Biosphere Reserve, Cameroon. Afr. Stud. Monogr. 2004; 25: 127.

[106] Kuete V, Fankam AG, Wiench B, Efferth T. Cytotoxicity and modes of action of the methanol extracts of six Cameroonian medicinal plants against multidrug -resistant tumor cells. Evid. Based Complement. Alternat. Med. 2013:285903. doi: $10.1155 / 2013 / 285903$

[107] Ngbolua KTN, Mubindukila REN, Mpiana PT, Ashande MC, Baholy R, Ekutsu GE et al. In vitro assessment of antibacterial and antioxidant activities of a congolese medicinal plant species Anthocleista schweinfurthii Gilg (Gentianaceae). J. Modern Drug. Discov. Drug. Deliv. Res. 2014; 7: 1-6. doi: 10.15297/JMDDR.V1I3.03

[108] Mbouangouere R, Tane P, Ngamga D, Khan S, Choudhary M, Ngadjui B. A New steroid and $\alpha$ glucosidase inhibitors from Anthocleista schweinfurthii. J. Med. Plants Res. 2007; 1: 106. doi: 10.3923/rjmp.2007. 106.111

[109] Kuete V, Tankeo SB, Saeed ME, Wiench B, Tane P, Efferth T. Cytotoxicity and modes of action of five Cameroonian medicinal plants against multifactorial drug resistance of tumor cells. J. Ethnopharmacol. 2014e; 153: 207-219. doi: 10.1016/j.jep.2014.02.025

[110] Adaramoye 0, Erguen B, Oyebode O, Nitzsche B, Hopfner $\mathrm{M}$, Jung $\mathrm{K}$ et al. Antioxidant, antiangiogenic and antiproliferative activities of root methanol extract of Calliandra portoricensis in 
human prostate cancer cells. J. Integr. Med.2015; 13: 185-193. doi: 10.1016/S2095-4964(15) 60175-3

[111] Aguwa CN, Lawal AM. Pharmacologic studies on the active principles of Calliandra portoticensis leaf extracts. J. Ethnopharmacol. 1988; 22: 63-71. doi: 10.1016/0378-8741(88)90231-0

[112] Ruppelt B, Pereira E, Goncalves L, Pereira N. Pharmacological screening of plants recommended by folk medicine as anti-snake venom I. Analgesic and anti-inflammatory activities. Mem. Inst. Oswaldo Cruz 1991; 86: 203-205. doi: 10.1590/S007402761991000600046

[113] Ngadjui B, Dongo E, Happi N, Bezabih M, Abegaz B. Prenylated flavones and phenylpropanoid derivatives from roots of Dorstenia psilurus. Phytochemistry 1998; 48: 733-737. doi: 10.1016/S00319422(98)00017-X

[114] Kuete V, Krusche B, Youns M, Voukeng I, Fankam AG, Tankeo $\mathrm{S}$ et al. Cytotoxicity of some Cameroonian spices and selected medicinal plant extracts. J. Ethnopharmacol. 2011a; 134: 803-812. doi: 10.1016/j.jep.2011.01.035

[115] Tabopda TK, Ngoupayo J, Awoussong PK, MitaineOffer AC, Ali MS, Ngadjui BT et al. Triprenylated flavonoids from Dorstenia psilurus and their alphaglucosidase inhibition properties. J. Nat. Prod. 2008; 71: 2068-2072. doi: 10.1021/np800509u

[116] Pieme CA, Ambassa P, Yankep E, Saxena AK. Epigarcinol and isogarcinol isolated from the root of Garcinia ovalifolia induce apoptosis of human promyelocytic leukemia (HL-60 cells). BMC Res. Notes 2015; 8:700. doi: 10.1186/s13104-015-1596-8

[117] Kuete V, Sandjo LP, Wiench B, Efferth T. Cytotoxicity and modes of action of four Cameroonian dietary spices ethno-medically used to treat Cancers: Echinops giganteus, Xylopia aethiopica, Imperata cylindrica and Piper capense. J. Ethnopharmacol. 2013; 149: 245-253. doi: 10.1016/j.jep.2013.06.029

[118] Tene M, Tane P, Sondengam BL, Connolly JD. Lignans from the roots of Echinops giganteus. Phytochemistry 2004; 65: 2101-2105. doi: 10.1016/j.phytochem.2004.05.014

[119] Sandjo L, Kuete V, Poumale P, Efferth T. Unprecedented brominated oleanolide and a new tetrahydrofurano-ceramide from Echinops giganteus. Nat. Prod. Res. 2016; 30: 2529-2537. doi: 10.1080/14786419.2015.1120724

[120] Eno A, Azah N. Effect of ethanolic extract from Elaeophorbia drupifera leaves on the gastrointestinal smooth muscle of the rabbit. Nigerian J. Physiol. Sci. 2004; 19: 60-68. doi: 10.4314/njps.v19i1.32637

[121] Kinghorn A, Evans F. Occurrence of ingenol in Elaeophorbia species. Planta Med. 1974; 26: 150-154. doi: 10.1055/s-0028-1097982

[122] Ahiahonu PW, Goodenowe DB. Triterpenoids from leaves of Elaeophorbia drupifera. Fitoterapia 2007; 78: 337-341. doi: 10.1016/j.fitote. 2007.02.002

[123] Voukeng IK, Nganou BK, Sandjo LP, Celik I, Beng VP, Tane $\mathrm{P}$ et al. Antibacterial activities of the methanol extract, fractions and compounds from Elaeophorbia drupifera (Thonn.) Stapf. (Euphorbiaceae). BMC Complement. Altern. Med. 2017; 17:28. doi: 10.1186/s12906-016-1509-y

[124] Kuete V, Voukeng IK, Tsobou R, Mbaveng AT, Wiench B, Beng VP et al. Cytotoxicity of Elaoephorbia drupifera and other Cameroonian medicinal plants against drug sensitive and multidrug resistant cancer cells. BMC Complement. Altern. Med. 2013e; 13:250. doi: 10.1186/1472-6882-13-250

[125] Burkill H. The Useful Plants of West Tropical Africa. London: Royal Botanic Garden Kew. 1985.

[126] Sowemimo A, Venables L, Odedeji M, Koekemoer T, Van De Venter M, Hongbing L. Antiproliferative mechanism of the methanolic extract of Enterolobium cyclocarpum (Jacq.) Griseb. (Fabaceae). J. Ethnopharmacol. 2015; 159: 257-261. doi: 10.1016/j.jep.2014.11.023

[127] Mabeku L, Kuiate J, Oyono E. Screening of some plants used in the Cameroonian folk medicine for the treatment of infectious diseases. Int. J. Biol. 2011; 3: 13-21. doi: 10.5539/ijb.v3n4p13

[128] Kuete V, Djeussi DE, Mbaveng AT, Zeino M, Efferth T. Cytotoxicity of 15 Cameroonian medicinal plants against drug sensitive and multi-drug resistant cancer cells. J. Ethnopharmacol. 2016a; 186: 196-204. doi: 10.1016/j.jep.2016.04.001

[129] Nishimoto K, Ito M, Natori S, Ohmoto T. (1968). The structure of arundoin, cylindrin and fernenol triterpenoids of fernane and arborane groups of Imperata cylindrica var. Koenigii. Tetrahedron 1968; 24: 735-752. doi: 10.1016/0040-4020(68)88023-8

[130] Mohamed G, Abdel-Lateff A, Fouad M, Ibrahim S, Elkhayat E, Okino T. Chemical composition and hepato-protective activity of Imperata cylindrica Beauv. Pharmacogn. Mag. 2009; 5: 28-36.

[131] Matsunaga K, Shibuya M, Ohizumi Y. Imperanene, a novel phenolic compound with platelet aggregation inhibitory activity from Imperata cylindrica. J. Nat. Prod. 1995; 58: 138-139. doi: 10.1021/np50115a022

[132] Keshava R, Muniyappa N, Gope R, Ramaswamaiah AS. Anticancer effects of Imperata cylindrica leaf extract on human oral squamous carcinoma cell line SCC-9 in vitro. Asian Pac. J. Cancer Prev. 2016; 17: 1891-1898. doi: 10.7314/APJCP.2016.17.4.1891

[133] Kwok AH, Wang Y, Ho WS. Cytotoxic and prooxidative effects of Imperata cylindrica aerial part ethyl acetate extract in colorectal cancer in vitro. Phytomedicine 2016; 23: 558-565. doi: 10.1016/j.phymed.2016.02.015

[134] Ibrahim B, Sowemimo A, Spies L, Koekomoer T, Van De Venter M, Odukoya OA. Antiproliferative and apoptosis inducing activity of Markhamia tomentosa leaf extract on HeLa cells. J. Ethnopharmacol. 2013; 149: 745-749. doi: 10.1016/j.jep.2013.07.040

[135] Ibrahim MB, Kaushik N, Sowemimo AA, Odukoya OA. Review of the phytochemical and pharmacological studies of the genus Markhamia. Pharmacogn. Rev. 2016; 10: 50-59. doi: 10.4103/0973-7847.176547

[136] Kuete V, Efferth T. Cameroonian medicinal plants: pharmacology and derived natural products. Front. Pharmacol. 2010; 1:123. doi: 10.3389/fphar.2010.00123

[137] Kuete V, Efferth T. (2011). Pharmacogenomics of Cameroonian traditional herbal medicine for cancer therapy. J. Ethnopharmacol. 2011; 137: 752-766. doi: 10.1016/j.jep.2011.06.035

[138] Kuete V, Fozing DC, Kapche WF, Mbaveng AT, Kuiate JR, Ngadjui BT et al. Antimicrobial activity of the methanolic extract and compounds from Morus mesozygia stem bark. J. Ethnopharmacol. 2009; 124: 551-555. doi: 10.1016/j.jep.2009.05.004

[139] Kapche GD, Fozing CD, Donfack JH, Fotso GW, Amadou D, Tchana AN et al. Prenylated arylbenzofuran derivatives from Morus mesozygia with antioxidant activity. Phytochemistry 2009; 70: 216-221. doi: 10.1016/j.phytochem.2008.12.014

[140] Nicolle E, Boccard J, Guilet D, Dijoux-Franca MG, Zelefac F, Macalou S et al. Breast cancer resistance protein (BCRP/ABCG2): new inhibitors and QSAR studies by a 3D linear solvation energy approach. Eur. J. Pharm. Sci. 2009; 38: 39-46. doi: 10.1016/j.ejps.2009.05.012

[141] Abbiw DK. Useful Plants of Ghana: West African Uses of Wild and Cultivated Plants. London: Intermediate Technology Publications. 1990. doi: $10.3362 / 9781780443737$ 
[142] Akabue P, Mittal H. Clinical evaluation of a traditional herbal practice in Nigeria: a preliminary report. J. Ethnopharmacol. 1982; 6: 355-359. doi: 10.1016/0378-8741(82)90056-3

[143] Madubunyi I. Anti-hepatotoxic and trypanocidal activities of the ethanolic extract of nauclea latifolia root bark. J. Herbs Spices Med. Plants 1995; 3: 23-53. doi: 10.1300/J044v03n02_04

[144] Elujoba A. Female infertility in the hands of traditional birth attendants in South-West Nigeria. Fitoterapia 1995; 66: 239-248.

[145] Anowi CF, Nnabuife CC, Mbah C, Onyekaba T. Antimicrobial properties of the methanolic extract of the leaves of Nauclea latifolia. Int. J. Drug Res. Technol.2012; 2: 45-55.

[146] Shigemori H, Kagata T, Ishiyama H, Morah F, Ohsaki A, Kobayashi J. Naucleamides, A-E, new monoterpene indole alkaloids from Nauclea latifolia. Chem. Pharm. Bull. 2003; 51: 58-61. doi: 10.1248/cpb.51.58

[147] Karou SD, Tchacondo T, Ilboudo DP, Simpore J. SubSaharan Rubiaceae: a review of their traditional uses, phytochemistry and biological activities. Pak. J. Biol. Sci. 2011; 14: 149-169. doi: 10.3923/pjbs.2011.149.169

[148] Kadiri H, Adegor E, Asagba S. Effect of aqueous Nauclea pobeguinii leaf extract on rats induced with hepatic injury. Res. J. Med. Plants 2007; 1: 139-143. doi: 10.3923/rjmp.2007.139.143

[149] Mesia GK, Tona GL, Penge O, Lusakibanza M, Nanga TM, Cimanga RK et al. Antimalarial activities and toxicities of three plants used as traditional remedies for malaria in the Democratic Republic of Congo: Croton mubango, Nauclea pobeguinii and Pyrenacantha staudtii. Ann. Trop. Med. Parasitol. 2005; 99: 345-357. doi: 10.1179/136485905X36325

[150] Kuete V, Sandjo LP, Mbaveng AT, Seukep JA, Ngadjui BT, Efferth T. Cytotoxicity of selected Cameroonian medicinal plants and Nauclea pobeguinii towards multi-factorial drug-resistant cancer cells. BMC Complement. Altern. Med. 2015f; 15:309. doi: 10.1186/s12906-015-0841-y

[151] Irvine R. Woody Plant of Ghana. London: Oxford University Press. 1961.

[152] Bouquet A, Debray M. Plantes Médicinales de Côte d'Ivoire. Paris: Mission ORSTOM. 1974.

[153] Ngadjui BT, Lontsi D, Ayafor JF, Sondengam BL. Pachypophyllin and pachypostaudins A and B: three bisnorlignans from Pachypodanthium staudtii. Phytochemistry 1989; 28: 231-234. doi: 10.1016/0031-9422(89)85044-7

[154] Yapi TA, Boti JB, Félix TZ, Ahibo AC, Tomi F, Bighelli A. Pachypodanthium Staudtii Engl \& Diels from Côte d'Ivoire: composition of leaf, stem bark and roots oils. Eur. J. Sci. Res. 2012; 69: 137-142.

[155] Ichimura T, Yamanaka A, Ichiba T, Toyokawa T, Kamada Y, Tamamura T et al. Antihypertensive effect of an extract of Passiflora edulis rind in spontaneously hypertensive rats. Biosci. Biotechnol. Biochem. 2006; 70: 718-721. doi: 10.1271/bbb.70.718

[156] Silva JR, Campos AC, Ferreira LM, Aranha Junior AA, Thiede A, Zago Filho LA et al. Extract of Passiflora edulis in the healing process of gastric sutures in rats: a morphological and tensiometric study. Acta. Cir. Bras. 2006; 21(Suppl. 2): 52-60. doi: 10.1590/S010286502006000800009

[157] Kannan S, Parimala B, Jayakar B. Antibacterial evaluation of the methanolic extract of Passiflora edulis. Hygeia. J. Drugs Med. 2011; 3: 46-49.

[158] Kokowaro J. Medicinal Plants of East Africa. Nairobi: EA Lit Bureau. 1976.

[159] Van Wyk B, Gericke N. Peoples Plants: A Guide to Useful Plants in Southern Africa. Pretoria: Brizza Publications. 2000.
[160] Kuete V, Ngameni B, Wiench B, Krusche B, Horwedel C, Ngadjui BT et al. Cytotoxicity and mode of action of four naturally occuring flavonoids from the genus Dorstenia: gancaonin Q 4-hydroxylonchocarpin, 6prenylapigenin, and 6,8-diprenyleriodictyol. Planta Med. 2011b 77: 1984-1989. doi: 10.1055/s-00311280023

[161] Kuete V, Sandjo LP, Wiench B, Efferth T. Cytotoxicity and modes of action of four Cameroonian dietary spices ethno-medically used to treat Cancers: Echinops giganteus, Xylopia aethiopica, Imperata cylindrica and Piper capense. J. Ethnopharmacol. 2013c; 149: 245-253. doi: 10.1016/j.jep.2013.06.029

[162] Kaou A, Mahiou-Leddet V, Canlet C, Debrauwer L, Hutter S, Azas N et al. New amide alkaloid from the aerial part of Piper capense L.f. (Piperaceae). Fitoterapia 2010; 81: 632-635. doi: 10.1016/j.fitote.2010.03.006

[163] Pedersen ME, Metzler B, Stafford GI, Van Staden J, Jager AK, Rasmussen HB. Amides from Piper capense with CNS activity - a preliminary SAR analysis. Molecules 2009; 14: 3833-3843. doi: 10.3390/molecules14093833

[164] Woguem V, Maggi F, Fogang HP, Tapondjoua LA, Womeni HM, Luana $\mathrm{Q}$ et al. Antioxidant, antiproliferative and antimicrobial activities of the volatile oil from the wild pepper Piper capense used in Cameroon as a culinary spice. Nat. Prod. Commun. 2013; 8: 1791-1796.

[165] Tshibangu JN, Chifundera K, Kaminsky R, Wright AD, Konig GM. Screening of African medicinal plants for antimicrobial and enzyme inhibitory activity. J. Ethnopharmacol. 2002; 80: 25-35. doi: 10.1016/S0378-8741(01)00409-3

[166] Jeruto P, Lukhoba C, Ouma G, Otieno D, Mutai C. Herbal treatments in Aldai and Kaptumo divisions in Nandi district, Rift valley province, Kenya. Afr. J. Tradit. Complement. Altern. Med. 2007; 5: 103-105.

[167] Focho D, Wt N, Fonge B. Medicinal plants of Aguambu - Bamumbu in the Lebialem highlands, southwest province of Cameroon. Afr. J. Pharm. Pharmacol. 2009; 3: 1-13.

[168] Bedir E, Toyang NJ, Khan IA, Walker LA, Clark AM. A new dammarane-type triterpene glycoside from Polyscias fulva. J. Nat. Prod. 2001; 64: 95-97. doi: $10.1021 / \mathrm{np} 0003589$

[169] Gouwakinnou GN, Lykke AM, Assogbadjo AE, Sinsin B. Local knowledge, pattern and diversity of use of Sclerocarya birrea. J. Ethnobiol. Ethnomed. 2011; 7:8. doi: 10.1186/1746-4269-7-8

[170] Braca A, Politi M, Sanogo R, Sanou H, Morelli I, Pizza C et al. Chemical composition and antioxidant activity of phenolic compounds from wild and cultivated Sclerocarya birrea (Anacardiaceae) leaves. J. Agric. Food Chem. 2003; 51: 6689-6695. doi: $10.1021 / \mathrm{jf030374m}$

[171] Njume C, Afolayan AJ, Green E, Ndip RN. Volatile compounds in the stem bark of Sclerocarya birrea (Anacardiaceae) possess antimicrobial activity against drug-resistant strains of Helicobacter pylori. Int. J. Antimicrob. Agents 2011; 38: 319-324. doi: 10.1016/j.ijantimicag.2011.05.002

[172] Armentano MF, Bisaccia F, Miglionico R, Russo D, Nolfi $\mathrm{N}$, Carmosino $\mathrm{M}$ et al. Antioxidant and proapoptotic activities of Sclerocarya birrea [(A. Rich.) Hochst.] methanolic root extract on the hepatocellular carcinoma cell line HepG2. Biomed. Res. Int. 2015:561589. doi: 10.1155/2015/561589

[173] Kuete V, Tangmouo JG, Penlap Beng V, Ngounou FN, Lontsi D. Antimicrobial activity of the methanolic extract from the stem bark of Tridesmostemon omphalocarpoides (Sapotaceae). J. Ethnopharmacol. 2006; 104: 5-11. doi: 10.1016/j.jep.2005.08.002 
[174] Kone WM, Atindehou KK, Kacou-N'douba A, Dosso M. Evaluation of 17 medicinal plants from Northern Cote d'Ivoire for their in vitro activity against Streptococcus pneumoniae. Afr. J. Tradit. Complement. Altern. Med. 2006; 4: 17-22.

[175] Kone WM, Atindehou KK, Terreaux C, Hostettmann K, Traore D, Dosso M. Traditional medicine in north Cote-d'Ivoire: screening of 50 medicinal plants for antibacterial activity. J. Ethnopharmacol. 2004; 93: 43-49. doi: 10.1016/j.jep.2004.03.006

[176] Kuete V, Fankam AG, Wiench B, Efferth T. Cytotoxicity and modes of action of the methanol extracts of six Cameroonian medicinal plants against multidrug-mesistant tumor cells. Evid. Based Complement. Alternat. Med. 2013a:285903. doi: $10.1155 / 2013 / 285903$

[177] Iwu M. Handbook of African Medicinal Plants. Boca Raton, FL: CRC Press. 1993.

[178] Kuete V, Krusche B, Youns M, Voukeng I, Fankam AG, Tankeo $\mathrm{S}$ et al. Cytotoxicity of some Cameroonian spices and selected medicinal plant extracts. J. Ethnopharmacol. 2011a; 134: 803-812. doi: 10.1016/j.jep.2011.01.035

[179] Okafor CI. The metabolic syndrome in Africa: current trends. Indian J. Endocrinol. Metab. 2012; 16: 56-66. doi: 10.4103/2230-8210.91191

[180] Tatsadjieu L, Essia Ngang J, Ngassoum M, Etoa F. Antibacterial and antifungal activity of Xylopia aethiopica, Monodora myristica, Zanthoxylum xanthoxyloides and Zanthoxylum leprieurii from Cameroon. Fitoterapia 2003; 74: 469-472. doi: 10.1016/S0367-326X(03)00067-4

[181] Osafo N, Obiri DD. Anti-inflammatory and antianaphylactic activity of xylopic acid isolated from the dried fruit of Xylopia aethiopica in mice. Planta Med. 2016; 81: S1-S381. doi: 10.1055/s-0036-1596165

[182] Kuete V, Sandjo LP, Mbaveng AT, Zeino M, Efferth T. Cytotoxicity of compounds from Xylopia aethiopica towards multi-factorial drug-resistant cancer cells. Phytomedicine 2015g; 22: 1247-1254. doi: 10.1016/j.phymed.2015.10.008

[183] Adaramoye OA, Sarkar J, Singh N, Meena S, Changkija B, Yadav PP et al. Antiproliferative action of Xylopia aethiopica fruit extract on human cervical cancer cells. Phytother. Res. 2011; 25, 1558-1563. doi: 10.1002/ptr.3551

[184] Ozkan M, Mutiso PB, Nahar L, Liu P, Brown S, Wang W et al. Zanthoxylum usambarense (Engl.) Kokwaro (Rutaceae) extracts inhibit the growth of the breast cancer cell lines MDA-MB-231 and MCF-7, but not the brain tumour cell line U251 in vitro. Phytother. Res. 2013; 27: 787-790. doi: 10.1002/ptr.4775
[185] He W, Van Puyvelde L, De Kimpe N, Verbruggen L, Anthonissen K, Van Der Flaas $\mathrm{M}$ et al. Chemical constituents and biological activities of Zanthoxylum usambarense. Phytother. Res. 2002; 16: 66-70. doi: 10.1002/ptr.849

[186] Akoachere J, Ndip R, Chenwi E, Ndip L, Njock T, Anong D. Antibacterial effect of Zingiber officinale and Garcinia kola on respiratory tract pathogens. East Afr. Med. J. 2002; 79: 588-592. doi: 10.4314/eamj.v79i11.8804

[187] Kato A, Higuchi Y, Goto H, Kizu H, Okamoto T, Asano N et al. Inhibitory effects of Zinziber officinale Roscoe derived components on aldose reductase activity in vitro and in vivo. J. Agric. Food Chem. 2006; 54: 66406644. doi: 10.1021/jf061599a

[188] Sakpakdeejaroen I, Itharat A. Cytotoxic compounds against breast adenocarcinoma cells (MCF-7) from Pikutbenjakul. J. Health Res. 2009; 23: 71-76.

[189] Kato A, Higuchi Y, Goto H, Kizu H, Okamoto T, Asano N et al. Inhibitory effects of Zinziber officinale Roscoe derived components on aldose reductase activity in vitro and in vivo. J. Agric. Food Chem. 2006; 54: 66406644. doi: 10.1021/jf061599a

[190] Kim J, Lee S, Park H, Yang J, Shin T, Kim Y et al. Cytotoxic components from the dried rhizomes of Zingiber officinale Roscoe. Arch. Pharm. Res. 2008; 31: 415-418. doi: 10.1007/s12272-001-1172-y

[191] Chrubasik S, Pittler MH, Roufogalis BD. Zingiberis rhizoma: a comprehensive review on the ginger effect and efficacy profiles. Phytomedicine 2005; 12: 684701. doi: 10.1016/j.phymed.2004.07.009

[192] Ali BH, Blunden G, Tanira MO, Nemmar A. Some phytochemical, pharmacological and toxicological properties of ginger (Zingiber officinale Roscoe): a review of recent research. Food Chem. Toxicol. 2008; 46: 409-420. doi: 10.1016/j.fct.2007.09.085

[193] Mbaveng AT, Kuete V . "Chapter 30: Zingiber officinale," in Medicinal Spices and Vegetables from Africa, ed V. Kuete (Amsterdam: Academic Press), 20017; 627-639. doi: 10.1016/B978-0-12-8092866.00030-3

[194] Plengsuriyakarn T, Viyanant V, Eursitthichai V, Tesana S, Chaijaroenku, W, Itharat A et al. Cytotoxicity, toxicity, and anticancer activity of Zingiber officinale Roscoe against cholangiocarcinoma. Asian Pac. J. Cancer Prev. 2012; 13: 4597-4606. doi: 10.7314/APJCP.2012.13.9.4597

[195] Santos PA, Avanço GB, Nerilo SB, Marcelino RI, Janeiro $\mathrm{V}$, Valadares MC et al. Assessment of cytotoxic activity of rosemary (Rosmarinus officinalis L.), turmeric (Curcuma longa L.), and ginger (Zingiber officinale R.) essential oils in cervical cancer cells (HeLa). Scientific World Journal 2016:9273078 doi: $10.1155 / 2016 / 9273078$ 
TABLE 1: SUMMARY OF INCLUDED STUDIES [66-78]

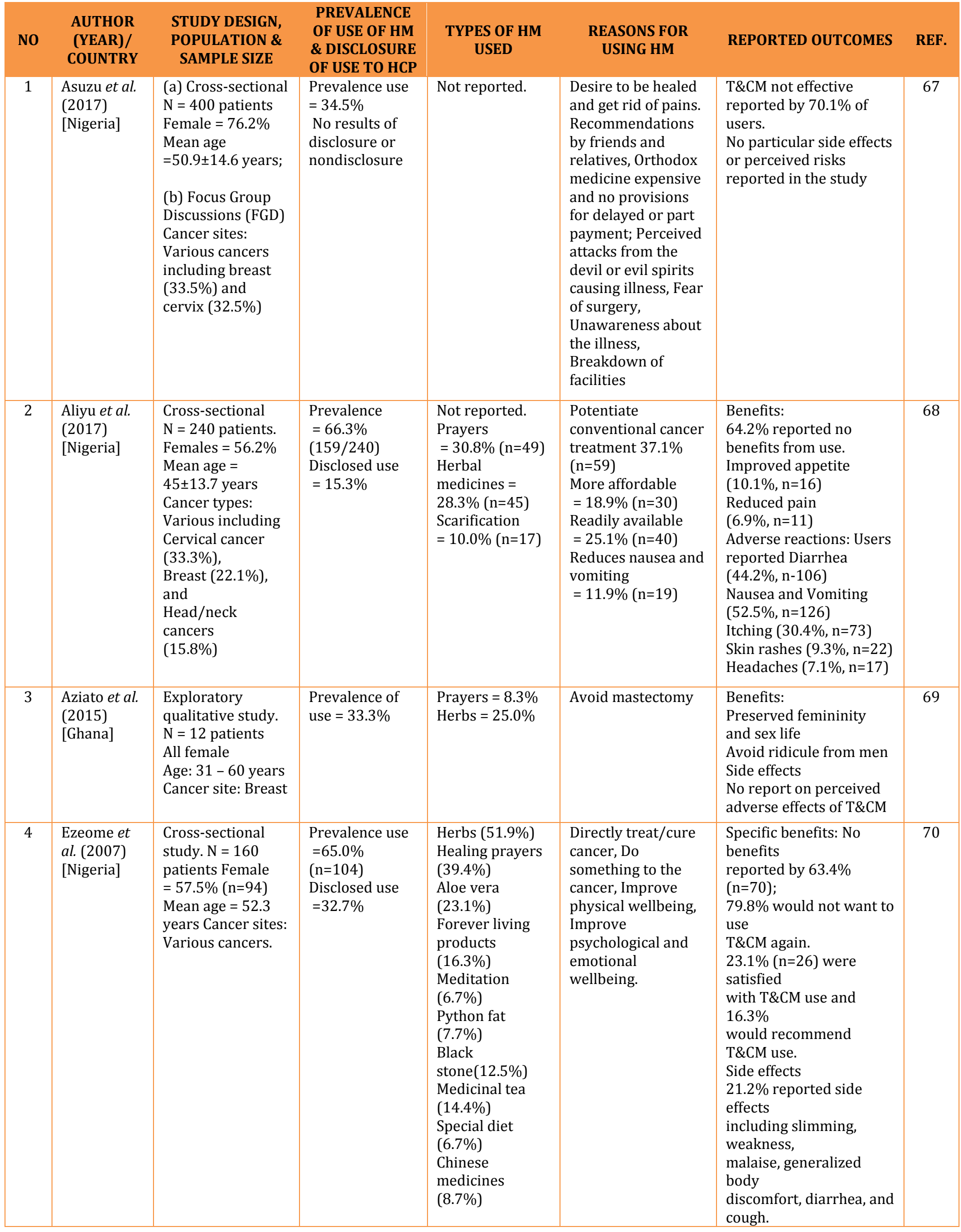




\begin{tabular}{|c|c|c|c|c|c|c|c|}
\hline NO & $\begin{array}{l}\text { AUTHOR } \\
\text { (YEAR)/ } \\
\text { COUNTRY }\end{array}$ & $\begin{array}{l}\text { STUDY DESIGN, } \\
\text { POPULATION \& } \\
\text { SAMPLE SIZE }\end{array}$ & $\begin{array}{l}\text { PREVALENCE } \\
\text { OF USE OF HM } \\
\text { \& DISCLOSURE } \\
\text { OF USE TO HCP }\end{array}$ & $\begin{array}{l}\text { TYPES OF HM } \\
\text { USED }\end{array}$ & $\begin{array}{l}\text { REASONS FOR } \\
\text { USING HM }\end{array}$ & REPORTED OUTCOMES & REF. \\
\hline 6 & $\begin{array}{l}\text { Erku et al. } \\
\text { (2016) } \\
\text { [Ethiopia] }\end{array}$ & $\begin{array}{l}\text { Cross-sectional } \\
\text { study. } \mathrm{N}=195 \\
\text { Female }=54.3 \% \\
\text { Age: } \geq 18 \text { years } \\
\text { Cancer sites: } \\
\text { Various including } \\
\text { breast }(37.9 \%)\end{array}$ & $\begin{array}{l}\text { Prevalence of } \\
\text { use }=79.0 \% \\
\text { Disclosed use } \\
=20.8 \%\end{array}$ & $\begin{array}{l}\text { Herbs }=72.1 \% \\
\text { Special foods } \\
=38.9 \% \\
\text { Spiritual healing } \\
=36.4 \% \\
\text { Dietary } \\
\text { supplements } \\
=22.1 \%\end{array}$ & $\begin{array}{l}\text { Belief in advantages } \\
=73.4 \% \\
\text { Dissatisfaction with } \\
\text { conventional } \\
\text { therapy }=14.9 \% \\
\text { Family tradition } \\
=13.0 \% \\
\text { Emotional support } \\
=11.0 \% \\
\text { Boost immunity } \\
=8.4 \%\end{array}$ & $\begin{array}{l}\text { Benefits: } \\
49.3 \%(n=76) \text { reported } \\
\text { satisfaction with use } \\
9.7 \%(n=15) \text { were } \\
\text { dissatisfied with use } \\
\text { Adverse effects: } \\
81.8 \%(n=126) \text { of users } \\
\text { reported no adverse } \\
\text { effects from T\&CM. }\end{array}$ & 72 \\
\hline 7 & $\begin{array}{l}\text { Kiraki et al. } \\
\text { (2019) } \\
\text { [Kenya] }\end{array}$ & $\begin{array}{l}\text { Cross-sectional } \\
\text { study. } \mathrm{N}=117 \\
\text { patients Female= } \\
53.8 \% \text { Age: } \geq 16 \\
\text { years Cancer sites: } \\
\text { Various including } \\
\text { breast }(13.7 \%) \\
\text { and cervix } \\
(12.8 \%)\end{array}$ & $\begin{array}{l}\text { Prevalence use } \\
=47.9 \% \\
\text { Disclosed use } \\
=85.7 \%\end{array}$ & $\begin{array}{l}\text { Spiritual therapy } \\
(37.5 \%, n=21) \\
\text { Vitamins and } \\
\text { supplements } \\
(26.5 \%, n=15) \\
\text { Herbs } \\
(19.6 \%, n=11) \\
\text { Chinese herbs } \\
(12.5 \%, n=7)\end{array}$ & $\begin{array}{l}\text { Cure of cancer } \\
=78.6 \% \\
\text { Improve immunity } \\
=44.6 \% \\
\text { Relieve cancer } \\
\text { symptoms } \\
=44.6 \% \\
\text { Manage pain } \\
=23.2 \%\end{array}$ & $\begin{array}{l}\text { Benefits: } \\
\text { Improved health } \\
(53.6 \%) \\
\text { Improved ability to cope } \\
(28.6 \%) \\
\text { Side effects } \\
\text { No T\&CM user reported } \\
\text { adverse effects }\end{array}$ & 73 \\
\hline 9 & $\begin{array}{l}\text { Mwaka et } \\
\text { al. } \\
\text { (2019) } \\
\text { [Uganda] }\end{array}$ & $\begin{array}{l}\text { Cross-sectional } \\
\text { study. } \\
\mathrm{N}=434 \text { patients } \\
\text { Female }=81.9 \% \\
(352 /) \\
\text { Mean age } \\
=49.2 \pm 12.2 \text { years } \\
\text { Cancer sites: } \\
\text { Breast }(71.9 \%), \\
\text { Stomach }(4.1 \%), \\
\text { Esophagus }(8.3 \%), \\
\text { Colorectal }(15.1 \%)\end{array}$ & $\begin{array}{l}\text { Prevalence use } \\
=55.6 \% \\
\text { Disclosed use } \\
=38.7 \%\end{array}$ & $\begin{array}{l}\text { Extracts from } \\
\text { leaves }=45.4 \% \\
\text { Bottled mixed } \\
\text { liquids }=43.3 \% \\
\text { Prayers }=28.8 \% \\
\text { Extracts from } \\
\text { roots }=25.0 \% \\
\text { Dry power herbs } \\
=17.9 \% \\
\text { Chinese } \\
\text { medicines } \\
=10.4 \%\end{array}$ & $\begin{array}{l}\text { Cure cancer } \\
=68.3 \% \\
\text { Improve immunity } \\
=35.6 \% \\
\text { Relieve pain } \\
=31.2 \% \text { Reduce } \\
\text { cancer symptoms } \\
=19.5 \% \text { Treat side } \\
\text { effects of } \\
\text { chemotherapy } \\
=16.8 \% \text { Prevent } \\
\text { cancer } \\
=8.6 \% \text { Potentiate } \\
\text { chemotherapy } \\
=6.6 \%\end{array}$ & $\begin{array}{l}\text { No report on perceived } \\
\text { benefits, risks or side } \\
\text { effects of } \\
\text { T\&CM }\end{array}$ & 75 \\
\hline 10 & $\begin{array}{l}\text { Nwankwo } \\
\text { et al. } \\
\text { (2019) } \\
\text { [Nigeria] }\end{array}$ & $\begin{array}{l}\text { Cross-sectional } \\
\text { study. } \\
\mathrm{N}=95 \text { patients } \\
\text { Female = } 100.0 \% \\
\text { Mean age } \\
=50.9 \pm 11 \text { years } \\
\text { Cancer sites: } \\
\text { Gynecological } \\
\text { including } \\
\text { cervix }(44.2 \%) \\
\text { and } \\
\text { ovary }(32.6 \%) .\end{array}$ & $\begin{array}{l}\text { Prevalence use } \\
=64.3 \%\end{array}$ & Herbs $=73.8 \%$ & Not reported & Not reported & 76 \\
\hline
\end{tabular}




\begin{tabular}{|c|c|c|c|c|c|c|c|}
\hline NO & $\begin{array}{l}\text { AUTHOR } \\
\text { (YEAR)/ } \\
\text { COUNTRY }\end{array}$ & $\begin{array}{l}\text { STUDY DESIGN, } \\
\text { POPULATION \& } \\
\text { SAMPLE SIZE }\end{array}$ & $\begin{array}{l}\text { PREVALENCE } \\
\text { OF USE OF HM } \\
\text { \& DISCLOSURE } \\
\text { OF USE TO HCP }\end{array}$ & $\begin{array}{l}\text { TYPES OF HM } \\
\text { USED }\end{array}$ & $\begin{array}{l}\text { REASONS FOR } \\
\text { USING HM }\end{array}$ & REPORTED OUTCOMES & REF. \\
\hline
\end{tabular}

TABLE 2: COMMON AFRICAN ANTICANCER HERBS AND THEIR MOLECULAR TARGETS [87-195]

\begin{tabular}{|c|c|c|c|c|c|c|}
\hline NO & $\begin{array}{c}\text { Plant species } \\
\text { and } \\
\text { family/distribu } \\
\text { tion in Central, } \\
\text { East and West } \\
\text { Africa }\end{array}$ & $\begin{array}{l}\text { Traditional } \\
\text { uses }\end{array}$ & $\begin{array}{l}\text { Bioactive or } \\
\text { potentially } \\
\text { bioactive } \\
\text { components }\end{array}$ & $\begin{array}{c}\text { Reported cytotoxic } \\
\text { activity* }\end{array}$ & $\begin{array}{l}\text { Molecular targets and/or effects } \\
\text { on resistant cells }\end{array}$ & REF. \\
\hline 1 & $\begin{array}{l}\text { Aframomum } \\
\text { arundinaceum } \\
\text { (Oliver \& } \\
\text { Hanbury) } \\
\text { K. Schum } \\
\text { (Zinziberaceae) } \\
\text { / Western and } \\
\text { Central Africa }\end{array}$ & $\begin{array}{l}\text { Anti-helmintic; } \\
\text { against body } \\
\text { odor; } \\
\text { toothache; } \\
\text { fungal } \\
\text { infections } \\
\text { (Tane et al., } \\
\text { 2005) }\end{array}$ & $\begin{array}{l}\text { Aframodial; } \\
\text { 8(17),12-labdadien- } \\
\text { 15,16- } \\
\text { dial;galanolactone; } \\
\text { galanal A; galanal B; } \\
\text { 1-p-menthene-3,6- } \\
\text { diol; 1,4- } \\
\text { dihydroxybenzene; } \\
\text { naringenin; } \\
\text { kaempferol-3,7,4 } \\
\text { '-trimethylether } \\
\text { (Kuete et al., 2014a) }\end{array}$ & $\begin{array}{l}\text { Cytotoxicity of fruit } \\
\text { methanol extract } \\
\text { toward CCRF-CEM cells, } \\
\text { CEM/ADR5000 cells, } \\
\text { MDA-MB-231-pcDNA } \\
\text { cells, MDA-MB-231- } \\
\text { BCRP cells, HCT116 } \\
\text { (p53 +/+) cells, HCT116 } \\
\text { (p53-/-) cells, U87MG } \\
\text { cells, U87MG.1EGFR } \\
\text { cells, HepG2 cells } \\
\text { (Kuete et al., 2014a) }\end{array}$ & $\begin{array}{l}\text { Hypersensitivity: CEM/ADR5000 } \\
\text { cells vs. CCRF-CEM cells (D.R. 0.76); } \\
\text { Normal sensitivity: MDA-MB-231- } \\
\text { BCRP cells vs. MDA-MB-231-pcDNA } \\
\text { cells (D.R. 1.02); U87MG.1EGFR } \\
\text { cells vs. U87MG cells (D.R. 0.95)( } \\
\text { Kuete } \text { et al., 2014a) }\end{array}$ & [87] \\
\hline
\end{tabular}


Plant species and family/distribution in Central, East and West Africa

\section{Traditional uses}

Reported cytotoxic activity*
Molecular targets and/or effects on resistant cells
$3 \quad$ Albizia adianthifolia

(Schum.)

(Fabaceae)/Angola

(Angola), Benin,

Cameroon, Central

African Republic

Congo, DR Congo,

Ivory Coast,

Equatorial Guinea,

Gabon, Gambia,

Ghana, Guinea,

Guinea-Bissau, Kenya,

Liberia,

Madagascar, Malawi,

Mozambique, Nigeria,

Rwanda, Senegal,

Sierra Leone, Sudan,

Tanzania, Togo,

Uganda

4 Alchornea cordifolia

(Schum. \& Thonn.)

Müll.-Arg.

(Euphorbiaceae)/

Tropical Africa from

Senegal to Kenya and

Tanzania and

throughout

Central Africa to

Angola

Annona muricata Lin.

(Annonaceae)/

Tropical Africa

including Cameroon

and Nigeria
Treatment of

skin diseases,

bronchitis, eyes

inflammation,

tapeworm,

headaches and

sinusitis (Watt

and Breyer-

Brandwyk,

1962; Van Wyk

and Gericke,

2000)

components

2002)

\begin{tabular}{|l|l|l} 
Adianthifoliosides & Cytotoxicity of the & Hypersensitivity: \\
A, B, D & methanol extract from & U87MG.1EGFR cells vs. \\
(Haddad et al., & bark and roots toward & U87MG cells \\
2003, 2004), & CCRF-CEM cells, & (D.R.: 0.43 (bark extract) \\
lupeol and & CEM/ADR5000 cells, & and 0.39 (roots extract)); \\
aurantiamide & MDA-MB-231-pcDNA & Roots methanol extract \\
acetate & cells, MDA-MB-231- & induces apoptosis in \\
(Tamokou J. D. D. & BCRP cells, & CCRF-CEM cells through \\
et al., 2012), & HCT116(p53+/+) cells, & caspases activation and \\
prosapogenins & HCT116 (p53-/-) cells, & MMP loss (Kuete et al., \\
(Haddad et al., & U87MG cells, & 2016e)
\end{tabular}

U87MG.1EGFR cells,

HepG2 cells

(Kuete et al., 2016e)

\section{Treat}

rheumatic

pains, fever

wounds,

diarrhea,

convulsions,

coughs,

gonorrhea,

yaws, ulcer

rheumatic

pains,

bronchial

troubles

(Ogungbamila

and

Samuelsson,

1990; Adeneye

et al., 2014)

Treatment of

wounds and

insomnia;

antiparasitic,

insecticidal

(Rajeswari et al., 2012)
Alchornine,

alchorneinone, gentisnic acid and yohimbine (Ogungbamila and Samuelsson, 1990)

Epomuricenins-A and $\mathrm{B}$,

montecristin,

cohibins- $A$ and $B$, muridienins- 1 and 2 , muridienins- 3 and 4,muricadienin and

chatenaytrienins- 1 ,

2 and 3 and sabadelin,murihex ol, donhexocin, annonacin $\mathrm{A}$ and annonacin B (Rajeswari et al., 2012), Annomuricin E (Zorofchian Moghadamtousi et al., 2015

\section{Cytotoxicity of the}

methanol extract from

bark

and roots toward CCRF-

CEM cells,

CEM/ADR5000 cells,

MDA-MB-231-pcDNA

cells, MDA-MB-231-

BCRP cells,

HCT116(p53+/+) cells,

U87MG cells,

U87MG.1EGFR cells

(Kuete et al., 2016e)

Cytotoxicity of fruit

pericarp, leave and seeds methanol extract toward

CCRF-CEM cells and

CEM/ADR5000 cells

(Kuete et al., 2016b),

HL60 cells, HL60AR cells, MDA-MB-231-pcDNA

cells, MDA-MB-231-

BCRP cells,

HCT116 (p53 +/+) cells,

HCT116 (p53 -/-) cells,

U87MG cells,

U87MG.1EGFR cells,

HepG2 cells

(Kuete et al., 2013c)
Hypersensitivity:

U87MG.1EGFR cells vs.

U87MG cells

(D.R.: 0.83 (leave extract)

and $<0.40$

(bark extract)); Leaves methanol extract induces apoptosis in CCRF-CEM cells through MMP loss

and increase ROS

production

(Kuete et al., 2016e)

Induced apoptosis in CCRFCEM cells mediated

by MMP loss (Kuete et al., 2016b); Capsules consisted of $100 \%$ pure, finely milled leaf/stem powder of the plant with no binders or fillers induces necrosis of PC cells by inhibiting cellular metabolism, downregulated the expression of molecules related to hypoxia and glycolysis in $\mathrm{PC}$

cells (Torres et al., 2012);

Ethyl acetate extract of leaves reduces the colonic aberrant crypt foci formation in rats and induced down-regulation of PCNA and Bcl-2 proteins and the up-regulation of Bax protein

(ZorofchianMoghadamtous i et al.,2015) 
Plant species and

NO family/distribution in Central, East and West Africa
Bioactive or

potentially

bioactive

components
Reported cytotoxic activity*
Molecular targets and/or effects on resistant cells

REF.

Alkaloids,

phenols,

saponins,

(oliv) Engl et Diels.

(Anonaceae)/

Central and West

Africa, including

the DR Congo, Congo,

Central African

Republic, Angola,

Ghana, Nigeria, Gabon

and Cameroon

feet, spider bite,

bronchitis,

dysentery, sterility caused by poison, gastroenteritis

(Thomas et al.,

2003); syphilis,

infectious diseases

Noumi and
Eloumou, 2011 ()

diarrhea, snake bite,

malaria (Betti,

2004), cancer

(Kuete et al., 2013a)

7 Anthocleista

schweinfurthii Gilg.

(Loganiaceae)/

Tropical Africa

:Nigeria to Ethiopia,

south to Angola,

Zambia and Tanzania

\section{Treatment of hernia,}

female sterility,

stomach-ache in

women, ovarian

problems, venereal

diseases, bronchitis,

fever, purgative,

malaria, hard

abscesses

anthelminthic, otitis,

pain, malaria,

cancers, venereal

diseases, bacterial

diseases (Ngbolua et

al., 2014)

8 Beilschmiedia acuta

Kosterm

(Lauraceae)/

Cameroon,

Central African

Republic

\section{Treatment of cancer} and gastrointestinal infections

(Kuete et al., 2014e) tannins, sterols,

triterpenes

(Kuete et

al.,2013a)
Cytotoxicity of the
methanol extract from

leaves toward

CCRF-CEM cells,

CEM/ADR5000 cells, MDA-MB-231-pcDNA cells,

MDA-MB-231-BCRP cells,

HCT116 (p53+/+) cells, HCT116 (p53-/-) cells, U87MG cells,

U87MG.1EGFR cells,

HepG2 cells

(Kuete et al.,2013a)

\section{Treatment of}

lumbago, pain relief prostate diseases, and constipation, gonorrhea, headaches and ophthalmic preparation (Adaramoye et al., 2015)
Polyphenols,

alkaloids,

terpenes and

steroids

(Ngbolua et al.,

2014),

schweinfurthiin

1 , bauerenone 2 ,

bauerenol 3, 1-

hydroxy-3,7,8

trimethoxy-

xanthone 4 and

1, 8-dihydroxy-

3,7 dimethoxy-

xanthone 5

(Mbouangouere

et al., 2007)

Flavonoids,

triterpenes,

phenols,

saponins,

alkaloids

(Kuete et al.,

2014e)

Cytotoxicity of fruit

methanol extract toward

CCRF-CEM cells,

CEM/ADR5000 cells,

MDA-MB-231-pcDNA

cells,

MDA-MB-231-BCRP cells,

HCT116 (p53+/+) cells,

HCT116 (p53-/-) cells

(Kuete et al., 2016a)

Cytotoxicity of the

methanol extract from

roots toward CCRF-CEM

cells, CEM/ADR5000 cells,

MDA-MB-231-pcDNA

cells,

MDA-MB-231-BCRP cells,

HCT116 (p53+/+) cells, HCT116 (p53-/-) cells, U87MG cells,

U87MG.1EGFR cells

(Kuete et al., 2014e)

\section{Saponins,}

tannins,

flavonoids and

glycosides

(Aguwa and

Lawal, 1988)
Cytotoxicity of the root

methanol extract toward

PC-3 cells and LNCaP cells
(Adaramoye et al.,2015)
Hypersensitivity:

U87MG.1EGFR cells vs.

U87MG

cells (D.R.: < 0.41);

Normal sensitivity:

CEM/ADR5000 cells

vs. CCRF-CEM cells

(D.R.:0.95); induces

apoptosis in CCRF-

CEM cells by

disruption of MMP and

increase ROS

production

(Kuete et al., 2013a)

Normal sensitivity:

CEM/ADR5000 cells

vs. CCRF-CEM cells

(D.R. 1.11);

HCT116 (p53-/-) vs.

HCT116 (p53+/+)

cells (D.R. 0.96)

(Kuete et al., 2014a)

Hypersensitivity

(leaves extract):

HCT116 (p53-/-)cells

vs. HCT116 (p53+/+)

cells (D.R.: 0.23);

induces apoptosis in

CCRF-CEM cells

(Kuete et al., 2014e)

Antiangiogenic activity

[110-111]

via inhibition of of the

growth of blood

capillaries on the

chicken

chorioallantoic

membrane, induces

DNA fragmentation in

PC-3 cells and LNCaP

cells

(Adaramoye et al.

2015) 


\begin{tabular}{|c|c|c|c|c|c|c|}
\hline NO & $\begin{array}{l}\text { Plant species and } \\
\text { family/distributi } \\
\text { on in Central, } \\
\text { East and West } \\
\text { Africa }\end{array}$ & $\begin{array}{l}\text { Traditional } \\
\text { uses }\end{array}$ & $\begin{array}{l}\text { Bioactive or potentially bioactive } \\
\text { components }\end{array}$ & $\begin{array}{c}\text { Reported } \\
\text { cytotoxic activity* }\end{array}$ & $\begin{array}{l}\text { Molecular targets } \\
\text { and/or effects on } \\
\text { resistant cells }\end{array}$ & REF. \\
\hline 10 & $\begin{array}{l}\text { Dorstenia psilurus } \\
\text { Welwitch } \\
\text { (Moraceae)/ } \\
\text { Tropical Africa } \\
\text { including } \\
\text { Angola, Cameroon, } \\
\text { Uganda,Tanzania, } \\
\text { Malawi, } \\
\text { Mozambique }\end{array}$ & $\begin{array}{l}\text { Treatment of } \\
\text { arthralgia, } \\
\text { cardiovascular } \\
\text { disorders, } \\
\text { rheumatism, } \\
\text { snakebites, } \\
\text { headache, } \\
\text { stomach } \\
\text { disorders, } \\
\text { diuretic, } \\
\text { tonic, stimulant, } \\
\text { analgesic, cancer } \\
\text { (Ruppelt et al., } \\
\text { 1991;Adjanohou } \\
\text { n et al.,1996; } \\
\text { Ngadjui et al., } \\
\text { 1998; Dimo et } \\
\text { al.,2001; Kuete } \\
\text { et al., 2011a) }\end{array}$ & $\begin{array}{l}\text { Psoralen; 2-sitosterol glucoside } \\
\text { analgesic } \\
\text { Ngadjui et al., } 1998 \text { ( ), dorsilurins } \\
\text { C, F-K (Tabopda et al., 2008) }\end{array}$ & $\begin{array}{l}\text { Cytotoxicity of } \\
\text { twigs methanol } \\
\text { extract toward } \\
\text { CCRF-CEM cells } \\
\text { and } \\
\text { CEM/ADR5000 } \\
\text { cells (Kuete } \text { et al., } \\
2011 \text { a), HL-60 cells } \\
\text { and PC-3 cells } \\
\text { (Pieme et al., 2013) }\end{array}$ & $\begin{array}{l}\text { Normal } \\
\text { sensitivity: } \\
\text { CEM/ADR5000 } \\
\text { cells vs. } \\
\text { CCRF-CEM cells } \\
\text { (D.R. 0.88) (Kuete } \\
\text { et al., 2011a), } \\
\text { induces apoptosis } \\
\text { on HL-60 cells by } \\
\text { the generation of } \\
\text { ROS, MMP loss, } \\
\text { modification in } \\
\text { the DNA } \\
\text { distribution and } \\
\text { enhance of G2/M } \\
\text { phase cell cycle } \\
\text { (Pieme et al., } \\
\text { 2013) }\end{array}$ & [112-116] \\
\hline 11 & $\begin{array}{l}\text { Echinops } \\
\text { giganteus var. lelyi } \\
\text { (C. D. Adams) A. } \\
\text { Rich. } \\
\text { (Composiatae)/ } \\
\text { Cameroon, } \\
\text { Ethiopia, } \\
\text { Rwanda, Sudan, } \\
\text { Tanzania, Uganda, } \\
\text { DR Congo }\end{array}$ & $\begin{array}{l}\text { Treatment of } \\
\text { cancer, heart } \\
\text { and gastric } \\
\text { troubles (Tene } \\
\text { et al., 2004; } \\
\text { Kuete et al., } \\
\text { 2011a) }\end{array}$ & $\begin{array}{l}\text { Lupeol, sitosteryl, } \\
\beta \text {-D-glucopyranoside oleanolide, } \\
\text { tetrahydrofurano-ceramide, } \\
\beta \text {-amyrin acetate (3), } \\
2 \text {-(penta-1,3-diynyl)-5-(4- } \\
\text { hydroxybut-1-ynyl)-thiophene, } \\
\text { 2-(penta-1,3-diynyl)-5-(3,4- } \\
\text { dihydroxybut1-ynyl)-thiophene, } \\
\text { 4-hydroxy-2,6-di-(3',4- } \\
\text { dimethoxyphenyl)-3, } \\
\text { 7-dioxabicyclo-(3.3.0)octane } \\
\text { (Tene et al., 2004; Sandjo } \\
\text { et al., 2016), 2-(penta-1,3-diynyl)- } \\
\text { 5-(4-hydroxybut-1-ynyl)- } \\
\text { thiophene, } \\
\text { candidone, ursolic acid and 4- } \\
\text { hydroxy2,6-di-(3',4'- } \\
\text { dimethoxyphenyl)- } \\
\text { 3,7dioxabicyclo-(3.3.0)octane } \\
\text { (Kuete et al., 2013c) }\end{array}$ & $\begin{array}{l}\text { Cytotoxicity of } \\
\text { rhizomes methanol } \\
\text { extract toward } \\
\text { CCRF-CEM cells } \\
\text { and } \\
\text { CEM/ADR5000 } \\
\text { cells (Kuete } \text { et al., } \\
\text { 2011a), HL60 cells, } \\
\text { HL60AR cells, } \\
\text { MDA-MB-231- } \\
\text { pcDNA cells, } \\
\text { MDA-MB-231- } \\
\text { BCRP cells, HCT116 } \\
\text { (p53+/+) cells, } \\
\text { HCT116 (p53-/-) } \\
\text { cells, U87MG cells, } \\
\text { U87MG.1EGFR } \\
\text { cells, HepG2 cells } \\
\text { (Kuete et al., } \\
\text { 2013c) }\end{array}$ & $\begin{array}{l}\text { Hypersensitivity: } \\
\text { HCT116 } \\
\text { (p53-/-) cells vs. } \\
\text { HCT116 (p53+/+) } \\
\text { cells (D.R.: 0.82); } \\
\text { Normal } \\
\text { sensitivity: } \\
\text { U87MG.1EGFR } \\
\text { cells vs. U87MG } \\
\text { cells(D.R. 0.92); } \\
\text { (Kuete } \text { et al., } \\
\text { 2013c); induces } \\
\text { apoptosis in } \\
\text { CCRF-CEM cells } \\
\text { via the loss of } \\
\text { MMP } \\
\text { (Kuete et al., } \\
\text { 2013c) }\end{array}$ & [117] \\
\hline 12 & $\begin{array}{l}\text { Elaeophorbia } \\
\text { drupifera (Thonn.) } \\
\text { Stapf. } \\
\text { (Euphorbiaceae)/ } \\
\text { from Guinea east } \\
\text { to Uganda and } \\
\text { from DR Congo } \\
\text { and Angola }\end{array}$ & $\begin{array}{l}\text { Treatment of } \\
\text { hypertension } \\
\text { and diabetes } \\
\text { (Eno and Azah, } \\
\text { 2004) }\end{array}$ & $\begin{array}{l}\text { Euphol, tirucallol, euphorbol, } \\
\text { ingenol elaeophorbate, } \\
\text { epitaraxerol, taraxerone, } \\
\text { friedelin, lup-20(29)-en-3-one or } \\
\text { lupenone, lupeol, olean-12-ene-3- } \\
\text { one, olean-12-ene-3-ol, } \\
\text { elaeophorbate } \\
\text { Kinghorn and Evans, 1974; } \\
\text { Ahiahonu and Goodenowe, 2007), } \\
\text { stigmasterol and } \\
\beta \text {-sitosterol, sitosterol-0- } \beta \text {-D } \\
\text {-xylopyranoside, } \\
3,3^{\prime}, 4^{\prime} \text {-tri-O-methylellagic acid, } \\
\text { afzelin } \\
\text { and quercetin-3-0- } \beta \text {-D- } \\
\text { xylopyranoside, } \\
\text { 3,3',4'-tri-O-methylellagic acid } \\
\text { 4-0- } \beta \text {-D-glucopyranoside, ellagic } \\
\text { acid-4-0- } \beta \text {-xylopyranoside-3, } \\
3^{\prime}, 4^{\prime} \text {-trimethyl ether } \\
\text { (Voukeng et al., 2017) }\end{array}$ & $\begin{array}{l}\text { Cytotoxicity of the } \\
\text { methanol extract } \\
\text { from leaves } \\
\text { toward CCRF-CEM } \\
\text { cells, } \\
\text { CEM/ADR5000 } \\
\text { cells, } \\
\text { MDA-MB-231- } \\
\text { pcDNA cells, } \\
\text { MDA-MB-231- } \\
\text { BCRP cells, } \\
\text { HCT116 (p53+/+) } \\
\text { cells, } \\
\text { HCT116 (p53-/-) } \\
\text { cells, } \\
\text { U87MG cells, } \\
\text { U87MG.1EGFR } \\
\text { cells, HepG2 cells } \\
\text { (Kuete } \text { et al., } \\
\text { 2013e) }\end{array}$ & $\begin{array}{l}\text { Hypersensitivity: } \\
\text { U87MG.1EGFR } \\
\text { cells vs. U87MG } \\
\text { cells (D.R.: 0.68); } \\
\text { Normal } \\
\text { sensitivity: } \\
\text { CEM/ADR5000 } \\
\text { cells vs. CCRF- } \\
\text { CEM cells (D.R.: } \\
\text { 1.12); HCT116 } \\
\text { (p53-/-) cells vs. } \\
\text { HCT116 (p53+/+) } \\
\text { cells (D.R.: 1.13) } \\
\text { (Kuete } \text { et al., } \\
\text { 2013e) }\end{array}$ & [118-123] \\
\hline
\end{tabular}


Plant species and

family/distributi

NO on in Central,

\section{Bioactive or potentially} bioactive components
Reported cytotoxic activity*
Molecular targets and/or effects on resistant cells
East and West

\section{Traditional uses} Africa
REF.

D-Limonene, terpineol

eugenol and

d-(+)-pinitol

(Sowemimo et al., 2015)

tumors, cold

(Jacq.)

Griseb.(Fabaceae)/

West Africa

(Burkill, 1985)

methanol extract from

leaves

toward HeLa cells and

MCF7 cells

Induces apoptosis

G2/M phase in HeLa cells and G1/G0 in

MCF7 cells; causes
Cytotoxicity of the

(Sowemimo et al., 2015)

6 $\alpha$-hydroxyphaseollidin

(9),

atalantoflavone (15),

bidwillon A (16)

neobavaisoflavone (35),

neocyclomorusin (36)

and Sigmoidin I (44)

arthritis,

rheumatism,

(Kuete et al., 2014c)

stomach troubles,

infectious diseases

and kidney diseases

(Burkill, 1985),

gastrointestinal

infections,venereal

diseases and leprosy

(Mabeku et al.

2011)

15 Gladiolus

quartinianus A.

Rich(Iridaceae)/

Cameroon, Senegal

to Ethiopia
Treatment of

gastrointestinal

infections

and cancer

(Kuete et al., 2013a)
Cytotoxicity of bark

methanol extract

toward

CCRF-CEM cells,

CEM/ADR5000 cells,

MDA-MB-231-pcDNA

cells,MDA-MB-231-

BCRP cells, HCT116

(p53+/+)cells, HCT116

(p53-/-) cells, U87MG

cells, U87MG.1EGFR

cells, HepG2 cells

(Kuete et al.,2016a)

Cytotoxicity of the methanol extract from

whole plant toward

CCRF-CEM cells,

CEM/ADR5000cells,
Alkaloids, anthocyanins,

anthraquinones,

phenols, saponins,

tannins, sterols,

triterpenes

(Kuete et al., 2013a)
MDA-MB-231-pcDNA

cells, MDA-MB-231-

BCRP cells, HCT116

(p53+/+)cells,

HCT116(p53-/-) cells,

U87MG.1EGFRcells

(Kuete et al.,2013a)

Imperata

cylindrica Beauv.

var. koenigii

Durand

et Schinz

(Poaceae)/Benin,

Burkina Faso, DR

Congo, Ivory Cost,

Gambia, Ghana,

Guinea,Kenya,

Liberia, Mali,

Mozambique,

Niger,Nigeria,

Senegal, Tanzania,

Togo, Uganda
Used as diuretic and Jaceidin, quercetagetin-3, anti-inflammatory and cancer agent (Nishimoto et al., 1968; Kuete et al., 2011a)
5, 6,3.'-tetramethyl ether, $\beta$-Sitosterol-3-0- $\beta$-Dglucopyranosy1-6"

- tetradecanoate

(Mohamed et al., 2009), imperanene (Matsunaga et al., 1995) cells, MiaPaca-2(Kuete

\section{Cytotoxicity of roots}

methanol extract

toward CCRF-CEM cells and CEM/ADR5000 et al., 2011a), HL60 cells, HL60AR cells MDA-MB-231-pcDNA cells, MDA-MB-231BCRP cells, HCT116 (p53+/+) cells, HCT116 (p53-/-) cells, U87MG cells,U87MG.1EGFR cells, HepG2 cells (Kuete et al.,2013c); cytotoxicity of leaves methanol extract against SCC-9 cells (Keshava et al., 2016) and against HT-29 cells (Kwok et al., 2016) and cells cycle arrest phosphatidylserine translocation

(Sowemimo et al., 2015)

Hypersensitivity: HCT116 (p53-/-) cells vs.HCT116 (p53+/+) cells (D.R. 0.83 );

U87MG.1EGFR cells vs. U87MG cells (D.R. 0.66 );

Normal sensitivity: CEM/ADR5000 cells vs. CCRF-CEM cells

(D.R. 1.08); induces apoptosis in CCRF-

CEM leukemia cells via disruption of the MMP (Kuete et al., 2014a)

Hypersensitivity:

U87MG.1EGFR cells vs. U87MG

cells (D.R.: <0.85);

Normal sensitivity:

HCT116(p53-/-)

cells vs. HCT116

(p53+/+) cells

(D.R.:1.12); induces apoptosis in CCRF-

CEM cells by

disruption of MMP

(Kuete et al., 2013a)

Hypersensitivity: CEM/ADR5000 cells vs. CCRF-CEM (D.R. 0.90 ) cells (Kuete et al.2011a),apoptosis in CCRF-CEM cells via the loss of MMP (Kuete et al., 2013c); leaves methanol extractvreduced the clonogenic potential and inhibited cell proliferation by arresting the cell cycle in the G2/M phase in SCC-9 cells as well as DNA fragmentation (Keshava et al.2016); Induced G2/M arrest and apoptosis in HT-29 cells mediated by caspase $3 / 7$ activation and ROS production (Kwok et al., 2016) 
Plant species and

family/distributi

NO on in Central,

East and West Africa

\section{Traditional uses}

Bioactive or potentially bioactive components
Reported cytotoxic activity*
Molecular targets and/or effects on resistant cells
REF.

\begin{tabular}{l|l} 
Cytotoxicity of the & Induces apoptosis
\end{tabular} $\beta$-sitosterol, paulownin palmitone, palustrine, 2-acetylnaphtho[2,3-b] furan-4,9-dione, 2-acetyl-6methoxy-naphtho[2,3-b] furan-4,9-dione, luteolin, luteolin-7-rutinoside, and luteolin-3',7-di-O-glucoside (Ibrahim et al., 2016)

moracins Q-U,

3beta-acetoxyurs-12-en-11one, marsformoxide, moracin $\mathrm{C}$, moracin $\mathrm{M}$, moracin $\mathrm{K}$, artocarpesin, cycloartocarpesin, morachalcone A

(Kapche et al., 2009; Kuete et al., 2009);

kushenol E, artochamin C moracin $\mathrm{C}$ and moracin $\mathrm{L}$ (Nicolle et al., 2009)

Smith. (Rubiaceae)/ West tropical Africa: from Ghana to

Gabon and DR Congo

Nauclea pobeguinii (Pobég. ex Pellegr.) Merr. ex E.M.A.

(Rubiaceae)/ South Tropical Africa:Angola, Zambia, West Tropical Africa: Burkina,Ghana, Guinea, GuineaBissau, Ivory Coast,Nigeria, Senegal, Sierra Leone, WestCentral Tropical Africa: Cameroon, Central African Republic, Congo, DR Congo, Gabon

\section{Naucleamides A,B,C,D,E} (Shigemori et al., 2003)

\begin{tabular}{l|l}
$\begin{array}{l}\text { Treatment of } \\
\text { gonorrhea }\end{array}$ & $\begin{array}{l}\text { Naucleamides A,B,C,D,E } \\
\text { (Shigemori et al., 2003) }\end{array}$
\end{tabular}

(Abbiw, 1990),

hypertension

(Akabue and Mittal, 1982),

gastrointestinal tract disorders

(Madubunyi, 1995), prolong menstrual flow (Elujoba, 1995), stomach pain, constipation, fever, diarrhea, dysentery (Anowi et al., 2012)

Used as abortive,

Treatment of stomachache, infectious diseases (Karou et al.,2011), jaundice

(Kadiri et al., 2007), fever,diarrhea, worm, malaria (Mesia et al.,2005)
Nauclefine 1 and 2 strictosamide, Carboxystrictosidine, methylangustoline,

3-0- $\beta$-D-fucosyl-quinovicacid,3-keto-quinovic-acid (Karou et al., 2011); angustoline (Zeches et al., 1985) 3-acetoxy-11-oxo-urs-12ene,p-coumaric acid, citric acid trimethyl ester, resveratrol, resveratrol $\beta$-D-glucopyranoside, strictosamide (Kuete et al., 2015f) methanol extract from leaves toward HeLa cells (Ibrahim et al., 2013)

Cytotoxicity of bark methanol extract toward CCRF-CEM cells, CEM/ADR5000 cells, MDA-MB-231-pcDNA cells, MDA-MB-231-BCRP cells, HCT116 (p53+/+) cells, HCT116 (p53 -/-) cells, U87MG cells,

U87MG.1EGFR cells, HepG2 cells

(Kuete et al., 2016a)

\section{Cytotoxicity of bark and} leave methanol extract toward CCRF-CEM cells, CEM/ADR5000 cells, MDA-MB-231-pcDNA cells, MDA-MB-231-BCRP cells, HCT116 (p53+/+) cells, HCT116 (p53-/-) cells (Kuete et al., 2016a)

Cytotoxicity of the methanol extract from CCRF-CEM cells, CEM/ADR5000 cells, MDA-MB-231-pcDNA cells, MDA-MB-231-

BCRP cells,

HCT116(p53+/+) cells, HCT116 (p53-/-) cells, U87MG cells, U87MG.1EGFR cells (Kuete et al., 2015f) bark and leaves toward

\section{and cell cycle arrest}

in HeLa cells in the

G0/G1; induces phosphatidylserine translocation and depolarization MMP (Ibrahim et al., 2013)

$[134,135]$

Normal sensitivity:

CEM/ADR5000 cells vs. CCRF-CEM cells (D.R. 1.04); HCT116 (p53-/-) cells vs. HCT116 (p53 +/+) cells (D.R. 0.95); U87MG.1EGFR cells vs. U87MG cells (D.R. 1.06)

(Kuete et al., 2014a)

Hypersensitivity: MDA-MB-231-BCRP cells vs. MDA-MB231-pcDNA cells (D.R. 0.80); HCT116 (p53-/-) cells vs. HCT116 (p53+/+) cells (D.R.0.88) Normal sensitivity: CEM/ADR5000 cells vs.CCRF-CEM cells (D.R. 0.98)

(Kuete et al., 2014a)

Hypersensitivity

$[87,128$ (bark extract): CEM/ADR5000 cells vs. CCRF-CEM cells MDA-MB-231BCRP cells vs. MDA-MB-231pcDNA cells (D.R.: 0.53); HCT116 (p53-/-) cells vs. cells (D.R.:0.54) U87MG.1EGFR cells vs. U87MG cells (D.R.:0.47) (D.R.: 0.80); HCT116 (p53+/+) 
Plant species and

family/distributi

on in Central

East and West Africa

\section{Traditional uses \\ Bioactive or potentially \\ bioactive components}

Reported cytotoxic activity*
Molecular targets and/or effects on resistant cells
21 Pachypodanthium

staudtii Engl \&

Diels(Annonaceae)

/Sierra Leone east

to the Central

African Republic

and south to

Gabon and DR

Congo
Treatment of

cancer, chest pain

(Irvine,1961);

bronchitis (Bouquet

and Debray,1974)

and oedema

(Ngadjui et al.,1989)

\section{$\beta$-selinene, $\beta$-bisabolene, \\ $\delta$-cadinene,}

\section{Treatment of \\ cancer, fungal \\ infections,}

(Passifloraceae)/
Central and East

including

Cameroon,

Tanzania, Uganda

inflammation,

insomnia and

anxiety,

antihypertensive

(Ichimura et al.,

2006),

gastric trouble

(Silva et al., 2006),

antioxidant

(Kannan et al., 2011)

23 Piper capense L.f.

(Piperaceae)/from Guinea to Ethiopia and south to

Angola,

Mozambique
Sleep inducing

remedy,

anthelmintic,

anticancer

(Kokowaro, 1976;

Van Wyk and

Gericke, 2000;

Kuete et al., 2011a) 2,4,5-trimethoxy-1-

vinylbenzene

(Yapi et al., 2012)
Ionone-I, ionone-II,

megastigma-5,8-dien-4-1, megastigma-5,8(Z)-diene4-1, 4,4a-Epoxy-4, 4adihydroedulan, 3hydroxyedulan, edulan-I, edulan-II, passifloric acid methyl ester

(Kannan et al., 2011)
Trimethoxystyrene, pachypostaudins A and B (Ngadjui et al., 1989);

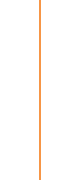

Polyscias fulva (Hiern) Harms. (Araliaceae)/

Tropical Africa -

Sierra Leone to

Sudan, Ethiopia to

Angola, Zambia

and

Mozambique

\begin{tabular}{|c|c|c|}
\hline $\begin{array}{l}\text { Malaria, fever, } \\
\text { mental illness } \\
\text { (Tshibangu } \\
\text { et al., 2002); } \\
\text { venereal infections } \\
\text { and obesity } \\
\text { (Jeruto et al., 2007; } \\
\text { Focho et al.,2009) } \\
\text { and cancer } \\
\text { (Kuete } \text { et al., 2014e) }\end{array}$ & $\begin{array}{l}\text { Polysciasoside A, } \\
\text { kalopanax-saponin B, } \\
\text { alpha-hederin } \\
\text { (Bedir } \text { et al., 2001; } \\
\text { Kuete and Efferth, 2011) }\end{array}$ & $\begin{array}{l}\text { Cytotoxicity of the } \\
\text { methanol extract from } \\
\text { roots and leaves toward } \\
\text { CCRF-CEM cells, } \\
\text { CEM/ADR5000 cells, } \\
\text { MDA-MB-231-pcDNA } \\
\text { cells, MDA-MB-231- } \\
\text { BCRP cells, HCT116 } \\
\text { (p53+/+) cells, HCT116 } \\
\text { (p53-/-) cells, U87MG } \\
\text { cells, U87MG.1EGFR } \\
\text { cells, HepG2 cells } \\
\text { (Kuete et al., 2014e) }\end{array}$ \\
\hline
\end{tabular}

Kaousine, Z-

antiepilepsirine (Kaou et al., 2010), piperine, 4,5dihydropiperine (Pedersen et al., 2009), beta-pinene, sabinene, alpha-pinene (Woguem et al., 2013)
Cytotoxicity of seeds methanol extract toward CCRF-CEM cells and CEM/ADR5000 (Kuete et al., 2011a), MDA-MB 231 cells, A375 cells, HCT116 cells (Woguem et al., 2013), HL60 cells, HL60AR cells, MDAMB-231-pcDNA cells, MDA-MB-231-BCRP cells, HCT116(p53+/+) cells, HCT116 (p53-/-) cells, U87MG cells, U87MG.1EGFR cells,

HepG2 cells (Kuete et al., 2013c) methanol extract from CCRF-CEM cells, CEM/ADR5000 cells, MDA-MB-231-pcDNA cells, MDA-MB-231(p53+/+) cells, HCT116 (p53-/-) cells, U87M S, HepG2 cells (Kuete et al., 2014e)
Hypersensitivity: [101, CEM/ADR5000

151-154]

cells vs.CCRF-CEM

cells (D.R. 0.87);

MDA-MB-231-

BCRP cells vs.

MDA-MB-231-

pcDNA cells (D.R.

0.90); Normal

sensitivity:

U87MG.1EGFR

cells vs. U87MG

cells (D.R. 1.05)

(Kuete et al., 2016b)

Induces apoptosis

in CCRF-CEM cells

mediated by MMP

loss (Kuete et al.,

2016b); fruit juice

reduces the

number, size, and

invasiveness of

transformed foci in

a BALB/c 3T3

neoplastic

transformation

model; activated

caspase- 3 in

MOLT-4 cells

(Rowe et al., 2004)

Hypersensitivity: CEM/ADR5000

[158-

cells vs.

CCRF-CEM cells

(D.R. 0.90)

(Kuete et al.,

2011a),

apoptosis in CCRF-

CEM cells via the

loss of MMP

and increase ROS

production (Kuete et al., 2013c)

[101,

155-157] Hypersensitivity: HCT116 (p53 -/-) cells vs.

HCT116 (p53 +/+) cells (D.R.: 0.41); induces apoptosis in CCRF-CEM cells via the alteration of MMP and enhanced ROS production (Kuete et al., 2014e) 


\begin{tabular}{|c|c|c|c|c|c|c|}
\hline No & $\begin{array}{c}\text { Plant species } \\
\text { and } \\
\text { family/distribut } \\
\text { ion in Central, } \\
\text { East and West } \\
\text { Africa }\end{array}$ & Traditional uses & $\begin{array}{l}\text { Bioactive or potentially } \\
\text { bioactive components }\end{array}$ & $\begin{array}{l}\text { Reported } \\
\text { cytotoxic } \\
\text { activity* }\end{array}$ & $\begin{array}{l}\text { Molecular targets } \\
\text { and/or effects on } \\
\text { resistant cells }\end{array}$ & REF. \\
\hline 25 & $\begin{array}{l}\text { Sclerocarya } \\
\text { birrea (A. Rich.) } \\
\text { Hochst. } \\
\text { (Anacardiaceae)/ } \\
\text { throughout most } \\
\text { of sub-Saharan } \\
\text { Africa outside the } \\
\text { humid forest } \\
\text { zone, from } \\
\text { Mauritania and } \\
\text { Senegal to } \\
\text { Ethiopia } \\
\text { and Eritrea, } \\
\text { Namibia, } \\
\text { Botswana, } \\
\text { Mozambique }\end{array}$ & $\begin{array}{l}\text { Treatment of } \\
\text { stomach aches, } \\
\text { diarrhea, wounds, } \\
\text { coughs } \\
\text { (Gouwakinnou et al., } \\
\text { 2011) }\end{array}$ & $\begin{array}{l}\text { Quercetin 3-O-alpha-l- }\left(5^{\prime \prime}-\right. \\
\text { galloyl)- arabinofuranoside, } \\
\text { quercetin 3-O } \beta-D-\left(6^{\prime \prime}-\right. \\
\text { galloyl)glucopyranoside, } \\
\text { quercetin 3- O- } \beta \text {-D- }\left(6^{\prime \prime}\right. \\
\text { - galloyl)galactopyranoside, } \\
\text { quercetin 3-0- } \alpha \text {-L- } \\
\text { rhamnopyranoside, } \\
\text { kaempferol 3- O- } \beta \text {-D- }\left(6^{\prime \prime}-\right. \\
\text { galloyl)glucopyranoside, } \\
\text { quercetin 3- } \beta \text {-D- } \\
\text { glucopyranoside, myricetin } \\
3-\text { - } \alpha \text {-L-rhamnopyranoside, } \\
\text { and kaempferol 3- O } \alpha-\mathrm{L}- \\
\text { rhamnopyranoside, gallic acid, } \\
(-) \text {-epicatechin 3-O-galloyl } \\
\text { ester, (-)-epigallocatechin 3-0- } \\
\text { galloyl ester Braca et al., 2003 } \\
(\text { ), terpinen-4-ol, } \\
\text { pyrrolidine, aromadendrene, } \\
\alpha \text {-gurjunene } \\
\text { (Njume et al., 2011) }\end{array}$ & $\begin{array}{l}\text { Cytotoxicity of the } \\
\text { methanol extract } \\
\text { from roots } \\
\text { toward HepG2 } \\
\text { cells (Armentano } \\
\text { et al., 2015) }\end{array}$ & $\begin{array}{l}\text { Induces apoptosis via } \\
\text { ROS production in } \\
\text { HepG2 cells } \\
\text { (Armentano et al., } \\
\text { 2015) }\end{array}$ & $\begin{array}{l}{[169-} \\
172]\end{array}$ \\
\hline 26 & $\begin{array}{l}\text { Tridesmostemon } \\
\text { omphalocarpoides } \\
\text { Engl. } \\
\text { (Sapotaceae)/ } \\
\text { Cameroon, } \\
\text { Gabon, Congo, DR } \\
\text { Congo }\end{array}$ & $\begin{array}{l}\text { Treatment of } \\
\text { gastroenteritis and } \\
\text { skin lesions } \\
\text { (Kuete et al., 2006) }\end{array}$ & $\begin{array}{l}\text { Alkaloids, phenols, } \\
\text { polyphenols, } \\
\text { saponins, tannins, triterpenes, } \\
\text { anthraquinones and steroids } \\
\text { (Kuete et al., 2006) }\end{array}$ & $\begin{array}{l}\text { Cytotoxicity of } \\
\text { bark methanol } \\
\text { extract toward } \\
\text { CCRF-CEM cells, } \\
\text { CEM/ADR5000 } \\
\text { cells, MDA-MB- } \\
\text { 231-pcDNA cells, } \\
\text { HCT116 (p53+/+) } \\
\text { cells,HCT116 } \\
\text { (p53-/-) cells, } \\
\text { U87MG cells } \\
\text { (Kuete et al., } \\
\text { 2016a) }\end{array}$ & $\begin{array}{l}\text { Normal sensitivity: } \\
\text { CEM/ADR5000 cells } \\
\text { vs.CCRF-CEM cells } \\
\text { (D.R. 0.99); HCT116 } \\
\text { (p53-/-)cells vs. } \\
\text { HCT116 (p53+/+) } \\
\text { cells (D.R. 1.15) } \\
\text { (Kuete } \text { et al., 2014a) }\end{array}$ & [173] \\
\hline 27 & $\begin{array}{l}\text { Uapaca togoensis } \\
\text { Pax } \\
\text { (Euphorbiaceae)/ } \\
\text { Tropical Africa } \\
\text { from Sierra Leone } \\
\text { to DR Congo; } \\
\text { Predominant in } \\
\text { Cameroon }\end{array}$ & $\begin{array}{l}\text { Antiemetic, lotion } \\
\text { for skin disorders } \\
\text { (Mengome et al., } \\
\text { 2010), remedy for } \\
\text { pneumonia, cough, } \\
\text { fever, rheumatism, } \\
\text { vomiting, epilepsy } \\
\text { (Kone et al., 2006) } \\
\text { and } \\
\text { bacterial diseases } \\
\text { (Kone et al., 2004) }\end{array}$ & $\begin{array}{l}\beta \text {-amyryl acetate, } 11 \text {-oxo- } \alpha \text { - } \\
\text { amyryl } \\
\text { acetate, lupeol, pomolic acid, } \\
\text { futokadsurin B, arborinin, } \\
\text { 3-0- } \beta \text {-D-glucopyranosyl } \\
\text { sitosterol (Kuete } \\
\text { et al., } 2015 \mathrm{e} \text { ) }\end{array}$ & $\begin{array}{l}\text { Cytotoxicity of the } \\
\text { methanol extract } \\
\text { from fruit } \\
\text { toward CCRF- } \\
\text { CEM cells, } \\
\text { CEM/ADR5000 } \\
\text { cells, } \\
\text { MDA-MB-231- } \\
\text { pcDNA cells, } \\
\text { MDA-MB-231- } \\
\text { BCRP cells, } \\
\text { HCT116 } \\
\text { (p53+/+) } \\
\text { cells, HCT116 } \\
\text { (p53-/-) cells, } \\
\text { U87MG cells, } \\
\text { U87MG.1EGFR } \\
\text { cells, HepG2 cells } \\
\text { (Kuete et al., } \\
\text { 2015e) }\end{array}$ & $\begin{array}{l}\text { Hypersensitivity: } \\
\text { MDA-MB-231-BCRP } \\
\text { cells vs. } \\
\text { MDA-MB-231-pcDNA } \\
\text { cells (D.R.: 0.16); } \\
\text { HCT116(p53-/-) } \\
\text { cells vs. HCT116 } \\
\text { (p53+/+) cells } \\
\text { (D.R.:0.84); } \\
\text { Normal sensitivity: } \\
\text { CEM/ADR5000 cells } \\
\text { vs. CCRF-CEM cells } \\
\text { (D.R.: 1.05); } \\
\text { U87MG.1EGFR cells } \\
\text { vs. U87MG cells } \\
\text { (D.R.: 1.08); induces } \\
\text { apoptosis in } \\
\text { CCRF-CEM cells by } \\
\text { MMP loss } \\
\text { (Kuete } \text { et al., 2015e) }\end{array}$ & $\begin{array}{l}{[174} \\
175]\end{array}$ \\
\hline
\end{tabular}




\begin{tabular}{|c|c|c|c|c|c|c|}
\hline NO & $\begin{array}{c}\text { Plant species } \\
\text { and } \\
\text { family/distribut } \\
\text { ion in Central, } \\
\text { East and West } \\
\text { Africa }\end{array}$ & Traditional uses & $\begin{array}{c}\text { Bioactive or } \\
\text { potentially bioactive } \\
\text { components }\end{array}$ & $\begin{array}{c}\text { Reported cytotoxic } \\
\text { activity* }\end{array}$ & $\begin{array}{l}\text { Molecular targets and/or } \\
\text { effects on resistant cells }\end{array}$ & REF. \\
\hline 28 & $\begin{array}{l}\text { Vepris soyauxii } \\
\text { Engl. (Rutaceae)/ } \\
\text { Throughout } \\
\text { West Africa, from } \\
\text { Sierra Leone, } \\
\text { Liberia, Ivory } \\
\text { Cost, Mali, Ghana } \\
\text { to Nigeria and } \\
\text { Cameroon }\end{array}$ & $\begin{array}{l}\text { Anti-fibriomyoma, } \\
\text { Treatment of } \\
\text { stomachache, } \\
\text { malaria } \\
\text { (Momeni et al., 2010) } \\
\text { and cancer } \\
\text { (Kuete et al., 2013a) }\end{array}$ & $\begin{array}{l}\text { Alkaloids, } \\
\text { anthocyanins, phenols, } \\
\text { tannins, sterols, } \\
\text { triterpenes } \\
\text { (Kuete et al., 2013a) }\end{array}$ & $\begin{array}{l}\text { Cytotoxicity of the } \\
\text { methanol extract } \\
\text { from leaves } \\
\text { toward CCRF-CEM } \\
\text { cells, CEM/ADR5000 } \\
\text { cells,MDA-MB-231- } \\
\text { pcDNA cells, MDA- } \\
\text { MB-231-BCRP cells, } \\
\text { HCT116 (p53+/+) } \\
\text { cells, HCT116 } \\
\text { (p53-/-) cells, } \\
\text { U87MG cells, } \\
\text { U87MG.1EGFR cells, } \\
\text { HepG2 cells } \\
\text { (Kuete et al.,2013a) }\end{array}$ & $\begin{array}{l}\text { Hypersensitivity: } \\
\text { U87MG.1EGFR cells vs. } \\
\text { U87MG cells (D.R.: 0.47); } \\
\text { Normal sensitivity: } \\
\text { HCT116(p53-/-) cells vs. } \\
\text { HCT116 (p53+/+) cells } \\
\text { (D.R.:1.12); induces } \\
\text { apoptosis in CCRF-CEM } \\
\text { cells mediated by } \\
\text { disruption of MMP } \\
\text { (Kuete } \text { et al., 2013a) }\end{array}$ & [176] \\
\hline 29 & $\begin{array}{l}\text { Xylopia } \\
\text { aethiopica } \\
\text { (Dunal)A.Rich. } \\
\text { (Annonaceae)/ } \\
\text { Angola, Benin, } \\
\text { Burkina Faso, } \\
\text { Cameroon, } \\
\text { Central African } \\
\text { Republic, DR } \\
\text { Congo, Ethiopia, } \\
\text { Gabon, Gambia, } \\
\text { Ghana,Guinea, } \\
\text { Guinea-Bissau, } \\
\text { Ivory Coast, } \\
\text { Kenya,Liberia, } \\
\text { Mozambique, } \\
\text { Nigeria, São } \\
\text { Tomé and } \\
\text { Príncipe,Senegal, } \\
\text { Sierra Leone, } \\
\text { Sudan, South } \\
\text { Sudan, Tanzania, } \\
\text { Togo, Uganda }\end{array}$ & $\begin{array}{l}\text { Treatment of cancer, } \\
\text { constipation; uterine } \\
\text { hemorrhage, diuretic, } \\
\text { fever } \\
\text { (Iwu, 1993; Kuete et } \\
\text { al., 2011a; Okafor, } \\
\text { 2012) }\end{array}$ & $\begin{array}{l}\text { Volatile oil (Tatsadjieu } \\
\text { et al., 2003), xylopic } \\
\text { acid (Osafo and Obiri, } \\
\text { 2016), 6 } \alpha \text {-hydroxy- } \\
\text { ent-kauran-19-oic } \\
\text { acid,3,4',5-trihydroxy- } \\
6^{\prime \prime}, 6^{\prime \prime} \\
\text { - dimethylpyrano } \\
\text { [2,3g]flavone,isotetran } \\
\text { drine (51) and trans- } \\
\text { tiliroside(Kuete et al., } \\
\text { 2015g), }\end{array}$ & $\begin{array}{l}\text { Cytotoxicity of seeds } \\
\text { methanol extract } \\
\text { toward } \\
\text { CCRF-CEM cells and } \\
\text { CEM/ADR5000 cells } \\
\text { Kuete } \text { et al., 2011a ( ), } \\
\text { C-33A cells, KB cells, } \\
\text { MCF-7 cells } \\
\text { (Adaramoye et al., } \\
\text { 2011), HL60 cells, } \\
\text { HL60AR cells, MDA- } \\
\text { MB-231-pcDNA cells, } \\
\text { MDA-MB-231-BCRP } \\
\text { cells, HCT116 } \\
\text { (p53+/+) cells, } \\
\text { HCT116 (p53-/-) } \\
\text { cells, U87MG cells, } \\
\text { U87MG.1EGFR cells, } \\
\text { HepG2 cells } \\
\text { (Kuete et al., 2013c) }\end{array}$ & $\begin{array}{l}\text { Hypersensitivity: } \\
\text { U87MG.1EGFR vs. U87MG } \\
\text { (D.R. 0.53); Normal } \\
\text { sensitivity: HCT116 } \\
\text { (p53-/-) cells } \\
\text { vs. HCT116 (p53+/+) cells } \\
\text { (D.R.: 1.05) } \\
\text { (Kuete } \text { et al.,2013c) } \\
\text {; induces apoptosis in } \\
\text { C-33A cells, nuclear } \\
\text { fragmentation, cells } \\
\text { accumulation in } \\
\text { sub-G0/G1, cycle arrest in } \\
\text { G2,up-regulation of p53 } \\
\text { and p21 genes, and an } \\
\text { increase in the Bax/Bcl-2 } \\
\text { ratio (Adaramoye et al., } \\
\text { 2011), apoptosis in CCRF- } \\
\text { CEM cells via the loss of } \\
\text { MMP (Kuete et al., 2013c) }\end{array}$ & $\begin{array}{c}{[117} \\
177-183]\end{array}$ \\
\hline 30 & $\begin{array}{l}\text { Zanthoxylum } \\
\text { usambarense } \\
\text { (Engl.) Kokwaro } \\
\text { (Rutaceae)/East } \\
\text { tropical Africa - } \\
\text { Ethiopia,Kenya, } \\
\text { Tanzania, eastern } \\
\text { DR Congo }\end{array}$ & $\begin{array}{l}\text { Treatment of } \\
\text { malaria, upper } \\
\text { respiratory } \\
\text { tract infections, } \\
\text { cough, rheumatism, } \\
\text { tooth decay } \\
\text { (Ozkan } \text { et al., 2013) }\end{array}$ & $\begin{array}{l}\text { Canthin-6-one, } \\
\text { pellitorine, } \\
\text { oxychelerythrine, } \\
\text { norchelerythrine, } \\
\text { (+)-sesamin, } \\
\text { (+)-piperitol-3, } \\
\text { 3-dimethylallyl ether } \\
\text { (He et al., 2002) }\end{array}$ & $\begin{array}{l}\text { Cytotoxicity of the } \\
\text { aqueous-methanol } \\
70 \% \text { extract from } \\
\text { aeral part toward } \\
\text { MDA-MB-231 } \\
\text { cells and MCF-7 cells } \\
\text { (Ozkan et al., 2013) }\end{array}$ & $\begin{array}{l}\text { Induces apoptosis in } \\
\text { MCF7 cells } \\
\text { (Ozkan et al., 2013) }\end{array}$ & $\begin{array}{l}{[184,} \\
185]\end{array}$ \\
\hline
\end{tabular}




\begin{tabular}{|c|c|c|c|c|c|c|}
\hline NO & $\begin{array}{c}\text { Plant species } \\
\text { and } \\
\text { family/distribut } \\
\text { ion in Central, } \\
\text { East and West } \\
\text { Africa }\end{array}$ & Traditional uses & $\begin{array}{c}\text { Bioactive or } \\
\text { potentially bioactive } \\
\text { components }\end{array}$ & $\begin{array}{c}\text { Reported cytotoxic } \\
\text { activity* }\end{array}$ & $\begin{array}{l}\text { Molecular targets and/or } \\
\text { effects on resistant cells }\end{array}$ & REF. \\
\hline 31 & $\begin{array}{l}\text { Zinziber } \\
\text { officinale Roscoe } \\
\text { (Zingiberaceae)/ } \\
\text { Tropical Africa }\end{array}$ & $\begin{array}{l}\text { Treatment of } \\
\text { infectious diseases, } \\
\text { respiratory tract } \\
\text { infections, cancer, } \\
\text { indidigestion, } \\
\text { diarrhea, nausea } \\
\text { (Akoachere } \text { et al., } \\
\text { 2002; Kato et al., } \\
\text { 2006; } \\
\text { Sakpakdeejaroen } \\
\text { and Itharat, 2009; } \\
\text { Kuete et al., 2011a) }\end{array}$ & $\begin{array}{l}\text { 2-(4-hydroxy-3- } \\
\text { methoxyphenyl) } \\
\text { Ethanol and } \\
\text { 2-(4-hydroxy-3- } \\
\text { methoxyphenyl) } \\
\text { Ethanoic acid } \\
\text { (Kato et al., 2006), } \\
\text { 6-shogaol } \\
\text { (Kim et al., 2008), } \\
\text { zingiberene,camphene } \\
\text {,ß-sesquiphellandrene, } \\
\beta \text {-bisabolene, } \\
\alpha \text {-farmesene, } \\
\text { curcumene, cineole, } \\
\text { citral, terpineol, } \\
\text { terpenes, borneol, } \\
\beta \text {-elemene, } \\
\text { zingiberenol, } \\
\text { limonene, geraniol, } \\
\text { zingiberol, linalool } \\
\text { (Chrubasik et al., } \\
\text { 2005;Ali et al., 2008; } \\
\text { Mbaveng and Kuete, } \\
\text { 2017) }\end{array}$ & $\begin{array}{l}\text { Cytotoxicity of } \\
\text { rhizomes methanol } \\
\text { extract toward CCRF- } \\
\text { CEM cells and } \\
\text { CEM/ADR5000 } \\
\text { cells, MiaPaca-2 cells } \\
\text { (Kuete et al., 2011a), } \\
\text { CL-6 cells } \\
\text { (Plengsuriyakarn et } \\
\text { al., 2012); } \\
\text { cytotoxicity of } \\
\text { essential oil against } \\
\text { HeLa cells } \\
\text { Santos et al., } 2016 \text { ( ) }\end{array}$ & $\begin{array}{l}\text { Hypersensitivity: } \\
\text { CEM/ADR5000 cells vs. } \\
\text { CCRF-CEM cells } \\
\text { (D.R. 0.88) (Kuete et al., } \\
\text { 2011a); ethanol extract } \\
\text { induces DNA } \\
\text { fragmentation and } \\
\text { up-regulation of MDR1 } \\
\text { and MRP3 genes in CL-6 } \\
\text { cells } \\
\text { (Plengsuriyakarn } \text { et al., } \\
\text { 2012) }\end{array}$ & $\begin{array}{l}{[186-} \\
195]\end{array}$ \\
\hline
\end{tabular}

*Reported cell lines: leukemia cells [CCRF-CEM, CEM/ADR5000, HL60, and HL60AR]; Carcinoma cells [A375 melanoma cells; C-33A and Caski cervix carcinoma cells; CL-6 cholangiocarcinoma cells; MDA-MB-231-pcDNA3 and MDA-MB-231-BCRP clone 23 breast cancer cells; HT-29, HCT116 (p53 +/+) and HCT116 (p53 -/-) colon cancer cells; KB and SCC-9 human oral squamous carcinoma cells; U87MG and U87MG.4EGFR glioblastoma cells; HeLa cervical carcinoma; HepG2 hepatocarcinoma; PC-3, MiaPaca-2 pancreatic cancer cells; LNCaP human prostatic adenocarcinoma, AML12 normal hepatocytes; BALB/c 3T3 fibroblasts];

D.R.: degree of resistance; D.R. is determined as the ratio of IC50 value in the resistant divided by the IC50 in the sensitive cell line; AML12, HL60AR, CEM/ADR5000, MDA-MB-231-BCRP, HCT116 (p53 -/-) and U87MG. $\triangle$ EGFR were used as the corresponding resistant counterpart for HepG2, HL60, CCRF-CEM, MDA-MB-231-pcDNA, HCT116 (p53 +/+), U87MG, respectively; Hypersensitivity, D.R. < 0.90; Normal sensitivity, D.R. 1 to 1.19; MMP, mitochondrial membrane potential; ROS, reactive oxygen species; (-), not report 